\title{
Does it matter if the President isn't pious? White Evangelicals and elite religiosity in the Trump era ${ }^{1}$
}

\author{
February 2021
}

Jack Thompson ${ }^{2}$

\begin{abstract}
s
Trump's unwavering support among White Evangelicals - among whom many believe that Trump was also ordained by God - seems a contradiction considering his seeming irreligiosity and well publicized moral transgressions. To explain this contradiction, I use data from the American Trends Panel (ATP) to test whether White Evangelicals exhibit strong preferences for elite religiosity, and whether they evaluate Trump as being particularly religious. I find that White Evangelicals exhibit strong, generalized preferences for elite religiosity. However, when it comes to specific evaluations of Trump, White Evangelicals appear to be largely indifferent to whether or not Trump is religious. I also find that White Evangelicals who encounter threats to their religious identities are especially likely to believe that Trump was ordained by God to be President. Therefore, one explanation for this seeming indifference is Trump's ability to speak to White Evangelicals who feel as though their beliefs are becoming marginalized in an increasingly religiously plural America. These findings demonstrate that Trump is a unique case when it comes to the effects of religiosity identity on elite evaluations, and provide a new vantage point for understanding why so many White Evangelicals support Trump despite the fact they are indifferent to his irreligiosity.
\end{abstract}

\footnotetext{
${ }^{1}$ Thanks to Adam Ozer for his thoughtful comments on a previous version of this paper. All errors are my own.

${ }^{2}$ Nottingham Trent University. Email: n0429992@ntu.ac.uk
} 


\section{Introduction}

Ever since Trump's victory in the 2016 Presidential election, scholars and commentators alike note his robust and unwavering body of support among White Evangelicals. 81 per cent of White Evangelicals reported voting for Trump in 2016 (Martinez and Smith 2016), a number that had declined by just 3 points come the 2020 election (Smith 2020). These trends are noteworthy considering that a group which was so mobilized by the Lewinsky scandal (Green et al. 2000) would exhibit such high levels of support for an elite who had an alleged extramarital affair with an adult film actress (Feuer 2018), and was also unable to name a single bible passage when asked which was his favorite (Merritt 2016). These developments have spurned a vast literature which has debated over why so many White Evangelicals are willing to support Trump given this apparent irreligiosity and wellpublicized moral transgressions (Whitehead et al. 2018; Wehner 2019; Ayris 2020; Margolis 2020; Whitehead and Perry 2020). The aim of my paper is to therefore provide some answers to an interesting contradiction that has been extensively hypothesized about, but has yet to be directly addressed.

The structure of the paper proceeds as follows. I begin by reviewing academic debates about religion as a social identity, noting how, since Trump's election in 2016, we have seen a burgeoning literature that has played close attention to assess how religious identities affect political behavior. I then provide an overview of the scholarship on the impact of religious identity on evaluations of the religiosity of elites, focusing on the effects of Evangelical identity on support for Republican candidates who use religious cues to mobilize support. With these streams of literature in mind, I draw attention to how Trump's seeming irreligiosity and moral transgressions give us reason to doubt whether or not Trump's religiosity matters at all to White Evangelicals. 
Next, I build a theoretical framework for thinking about why so many White Evangelicals not only support Trump, but think that God ordained him to be President - an interesting and seemingly contradictory finding given his aforenoted irreligiosity and welldocumented personal behavior. Drawing on contemporary debates in the Christian nationalism and religious psychology scholarship, I posit that White Evangelicals who perceive threats to their religious identity are likely to believe that God ordained Trump to be President to arrest the specific decline of Christian America. I hypothesize that it is these religious identity threats that condition White Evangelicals beliefs in whether Trump's election was a divine outcome. If White Evangelicals do believe that God chose Trump to President to address the perceived marginalization of their beliefs, then this finding may go some way in explaining why some 81 per cent of them support Trump despite his irreligiosity.

Overall, I find that White Evangelicals place a robust emphasis on the importance of having a President who stands up for their religious beliefs and exudes a number of religious qualities. However, when it comes to evaluations of Trump's religiosity, I find that White Evangelicals are largely indifferent to whether or not he is religious. In a further test of this hypothesis, White Evangelicals appear to be able to evaluate the religiosity of a slate of Democratic and Republican elites beyond Trump, suggesting Trump represents something of a unique case when it comes to the effects of religious identity on elite evaluations. Lastly, I find that White Evangelicals consider themselves to be minorities as a result of their religious beliefs, and that these evaluations condition their beliefs about whether God played a role in Trump's election.

These findings contribute to the political science literature in a number of ways. First, my analysis builds on work on religious descriptive representation by demonstrating that White Evangelicals exhibit strong, generalized preferences for elite religiosity. Second, 
despite a number of scholars highlighting the seeming contradiction between Trump's irreligiosity and his robust support among White Evangelicals, no studies that I am aware of have directly analysed their evaluations of his religiosity. My analysis goes thus some way to addressing this question by analyzing empirical data, and by demonstrating that Trump is something of a unique case when it to White Evangelicals and their beliefs about the importance of elite religiosity.

\section{White Evangelicals and Social Identity Theory}

Individuals who identify strongly with their religious group not only share a set of common beliefs, but also perceive their group memberships as central to their idea of self, thereby gaining a sense of self-esteem from group membership and a robust link to fellow group members (Tajfel and Turner 1979; Ysseldyk et al. 2010). The unique characteristics of religion including compelling affective experiences and a sense of moral authority (Wellman Jr and Tokuno 2004. Such characteristics lend religious social identities a personal importance which exceeds that of other group memberships. Religious identities have emerged as important explanatory measures in recent times (Margolis 2018). Many analyses have come in the wake of the 2016 US Presidential election, which revealed an electorate highly polarized along the lines of religion. Thus it is unsurprising to find an emergent scholarship pointing to the importance of group identities conditioning political behavior in the Trump era. ${ }^{3}$ In addition to these works, scholars play close attention to how religion

\footnotetext{
${ }^{3}$ Nonetheless, a growing body of scholarship indicates that group identities are endogenous to politics (Egan 2020). For instance, research finds Democrats and liberals switching into identification as non-religious (Campbell et al. 2018; Margolis 2018).
} 
affects the political behavior of White Americans, finding a consistent ${ }^{4}$ link to White Evangelicalism and support for Trump (Marti 2019; Margolis 2020).

\section{Elite Religiosity and the Impact of Religious Identity}

While many have questioned Trump's relative popularity among White Evangelicals given his perceived lack of religiously and well-documented personal transgressions (Whitehead et al. 2018; Wehner 2019; Ayris 2020; Whitehead and Perry 2020), we have not yet seen an analysis that directly addresses the question of Trump's religiosity with empirical data. The closest that an empirical analysis that has come to addressing this question is Margolis (2020). Margolis (2020) uses support for Trump among highly devout Evangelicals as a proximate measure of elite religious evaluations, finding that those with higher levels of religiosity were more reticent to support Trump in the initial stages of the 2016 Republican Presidential primaries. While these findings provide evidence that non-traditional candidates such as Trump were less likely to enjoy the support of devout Evangelicals in 2016, it is important to qualify that they do not offer direct evidence of their specific evaluations of Trump's religiosity.

Trump's seeming irreligiosity and personal transgressions bring into question the relative impact of elite religiosity on elite evaluations and voter behavior. Elite religiosity is conceptualized as an emphasis on the importance of religious descriptive representation among individuals who are highly religious themselves. While the descriptive representation scholarship has focused on the impact readily-visible identities such as race (Schildkraut

\footnotetext{
${ }^{4}$ The shortcomings of fusing "White" and "Evangelical" into a category are nonetheless noted by scholars. Some highlight the fact that there are intra-White Evangelical divisions over Trump (Bacon Jr and ThomsonDeVeaux 2018). Likewise, even though the changing racial demographics of Evangelicalism have provided fruitful exploration for scholars (Alexander 2020), non-White Evangelical remains a largely explored category in public opinion data, thus producing a "racially myopic" view of Evangelical Christianity (Ayris 2020).
} 
2017), it is likely that identities such as religion, which can easily be hidden from public view, function in a similar manner to those which cannot be easily hidden (Haider-Markel 2007). Consistent with this observation, studies find religious identity to have a substantive impact on evaluations of elites (Castle et al. 2017; Schmidt and Miles 2017). Given these streams of scholarship, I expect that White Evangelicals exhibit a broad desire for elites who exude religiosity and are also willing to stand up for their religious group interests. My first hypothesis is thus stated as:

H1: White Evangelicals will exhibit strong preferences for elite religiosity.

The American public know notoriously little about elite policy positions or voting records, largely relying on "informational shortcuts" when making evaluations about elites (Popkin 2020). In this way, elite identity cues help the public evaluate their ideological orientations, likely positions, and even personality traits. Identity markers such as religious affiliation and religiosity thus function as heuristics that allow the public to make evaluations about which elites will best represent them (McDermott 2009). Consistent with this theorizing, scholars find religious cues to have a substantive effect on elite approval, elite evaluations, and voter behavior (Campbell et al. 2008; Olson and Warber 2008; Calfano and Djupe 2009; Weber and Thornton 2012).

Elites who frame themselves as being religious are more likely to attract support from highly religious voters whilst repelling less-devout individuals (McLaughlin and Wise 2014). Republican elites often deploy covert cues to mobilize religious support (Albertson 2015). Covert cues do not directly reference God or their Christian faith (Calfano and Djupe 2009), instead relying on specific references to biblical passages that are detected by religious groups such as Evangelical Protestants who are typically loyal to the Republican Party 
(Schwadel 2017). A salient and practical example of covert cues includes Ted Cruz directly quoting scripture after victory in the 2016 Iowa Caucuses (Blair 2016).

This observation is interesting considering the specific case of Trump. Trump's attempt to use covert cues to mobilize Evangelical support is noteworthy because of his apparent lack of awareness of specific bible passages (Merritt 2016). If the attempted use of covert cues by Trump has not proved effective in convincing White Evangelicals of his religiosity, then we have reason to suspect that they will not perceive him as being particularly religious. ${ }^{5}$ Another reason to doubt whether White Evangelicals perceive Trump as being religious are his well-publicised personal transgressions, including his alleged extramarital affair with the adult-film actress Stormy Daniels. Given the Christian Right's reaction to the Lewinsky Scandal (Green et al. 2000), it is not out of the realm of possibility that some reacted the same way to Trump. ${ }^{6}$ These developments lead thus me to state my second hypothesis:

H2: White Evangelicals will not evaluate Trump as being particularly religious.

\section{Declining Influence, Marginalized Beliefs, and Elections as Divine Outcomes}

While religious cleavages were once shaped by religious tradition, social changes beginning in the Fifties led to "religious restructuring" whereby religious commitment played an increasingly vital role in structuring individual differences (Layman 2001). Resultingly,

\footnotetext{
${ }^{5}$ Scala's (2020) recent analysis of voter behavior the 2016 Republican Presidential primaries lends some weight to this possibility, finding that Evangelicals who were less devoted to their religion were more supportive of Trump than highly devout Evangelicals (who, in theory, should be the most receptive to covert cues) in the early stages of the primary.

${ }^{6}$ Though, it is important to note that these incidents require satisfaction of the ignorability assumption. Moreover, even if religious adherents are aware of such scandals, their reactions are also likely conditioned by negative partisanship (Margolis 2020).
} 
the religiously committed had a greater propensity to incorporate religion into their social identifies, were exposed to culturally traditional religious doctrine, and became more embedded in social networks that communicated distinctive political values (Castle 2019a). The sum of these changes was an emergent "culture war" (Hunter 1992) over issues including public education (Zimmerman 2009), abortion (Mouw and Sobel 2001), and later same sex marriage and transgender rights (Castle 2019b).

Over time, elites have fueled the culture wars by using cultural issues and feelings of threat $^{7}$ from putative outsiders to mobilize culturally aggrieved voters (Frank 2004). Indeed, as the percentage of Americans who do not identify with organized religion has declined (Putnam et al. 2012), White Christians are now a minority in American politics, a trend which has fed into perceptions of declining influence among many White Evangelicals (Jones 2016). As America becomes an increasingly plural nation along religious lines, elites such as Trump have come to view these changes as an opportunity to activate cultural threat and mobilize support among those who feel as though their beliefs are becoming increasingly marginalized as a result consequence of these changes. It is with these developments in mind that lead me to state my third hypothesis:

H3: White Evangelicals will have a high probability of considering themselves minorities because of their beliefs.

\footnotetext{
7 The perceived implications of an identity threat may elicit varying degrees of distress depending on the group membership that is targeted (Branscombe et al. 1999). Threats to some identities, such as religious identities, may be perceived as having greater implications than threats to identities associated with other groups. A threat to religious identity could be perceived as being paramount because of the "eternal" significance of religious group membership and the highly revered belief system to which it is attached (Kinnvall 2004).
} 
Nonetheless, Trump's ability to mobilize White Evangelical support seems puzzling when we consider the fact that he appears to know very little about the bible (Merritt 2016) or that some see his personal behavior as unbecoming of a devout Christian. Does Trump's behavior, as well as an apparent lack of religiosity, not matter at all to White Evangelicals? This question beget a point made by numerous scholars regarding Trump's relationship with White Evangelicals; Trump may not share their in terms of religion and lifestyle, but does share - and, most importantly, articulates on their behalf - many of the same grievances (Posner 2020; Whitehead et al. 2018). Indeed, and perhaps the most crucial grievance articulated by Trump, is the idea that the aforenoted changes that have occurred since the Fifties robbed White Evangelicals of the Christian America that many believed was God's intention for America's founding (Gorski 2019; Whitehead and Perry 2020).

Even if White Evangelicals think that Trump is not particularly religious, there is reason to suspect that they support him on a political level because of the many policies championed by Trump that have sought to further White Christian interests. Crucially, these policy "wins" may overpower concerns related to his lack of religiosity or personal behavior, since they seek to arrest the apparent decline in Christian influence that has led many White Evangelicals to feel as though they are now, themselves, minorities. While public beliefs do not crystalize into well-formed policy preferences (Achen and Bartels 2017) or are simply not attuned to which elites favor which policy (Oliphant 2016), evidence suggests that policy does matter to White Evangelicals (Keenan and Pereira 2020). This observation is important because Trump has largely delivered in policy areas such as court appointments, where many White Evangelicals are single-issues voters. ${ }^{8}$

Given Trump's articulation of the Christian nation myth and his relative success in enacting policies to arrest the apparent decline in White Christian influence, it is perhaps not

\footnotetext{
${ }^{8}$ Trump appointed 226 federal judges during his term - the most by any first term President since Jimmy Carter.
} 
surprising to find that some 73 percent of White Evangelicals believe that God played some role in his election in $2016 .{ }^{9}$ The idea that God ordained Trump to be President has been especially prevalent among Evangelical leaders including Ralph Reed (2020) and Robert Jeffress (Mooney 2019). White Evangelicals' specific rationale for divine influence varies. Some common rationales include the idea that Trump is fulfilling America's destiny or restoring America as a Christian nation (Posner 2020), which fits directly with the Christian nationalism thesis (Whitehead and Perry 2020). An addendum to this rationale is the idea that God choses unlikely leaders to represent his followers (Posner 2020). The allegory here being that Trump may not be a Christian, but his followers nonetheless see him as restoring a version of a Christian America just as biblical characters such as King Cyrus, the Persian King, restored Jerusalem.

This rationale is important to consider because it may explain why so many White Evangelicals think that God ordained Trump to be President even if he is not an overtly devout follower of the Christian faith. Religious psychology scholars posit that threats to religious identity are especially salient because they may lead to individuals adopting "coping mechanisms," including passive resignation to the threat itself, as well as wishful thinking (Ysseldyk et al. 2011). The belief that God chose Trump to be President could be an example of wishful thinking on the part of White Evangelicals especially concerned about the decline of a White Christian America. In this model, White Evangelicals perceive that Christian America is declining, making them feel as though they are a religious minority. Political elites then frame issues such as the decline of Christian America in a way that appeals to these threat perceptions. In the specific case of Trump, this includes harks to the restoration of a "Christian America" (Whitehead et al. 2018). In this way, identity threat perceptions are activated by the specific frame regarding the "restoration" of Christian America as promoted

\footnotetext{
${ }^{9}$ Estimates based off my descriptive analysis of Pew data.
} 
by Trump, with the activation of these frames depending on the degree of resonance between the threat perceptions themselves and White Evangelicals' belief in Trump's message. Given that religious identity threats explain support for Trump (Whitehead et al. 2018), we therefore have reason to expect that they will also condition their beliefs about God's role in Trump's election. These developments lead me to state my fourth and final hypothesis:

H4: Perceptions of minority status will condition White Evangelical beliefs about God's role in Trump's election.

\section{Definitions, Data, and Measures}

A definitional issue must first be addressed before proceeding to outline my data and measures. Despite being a pervasive group of scholarly interest since Trump's election in 2016, Evangelicals are defined in a number of different ways. How Evangelicals are defined is important because different coding schema may elicit diverging inferences about the group in question (Hackett and Lindsay 2008; Ayris 2020). Burge and Lewis (2018a) posit that a question about broad religious affiliation followed by a question about a respondents' status as a "born again" or Evangelical Christian is sufficient. However, this approach may lead to a sample that is smaller and slightly more Republican-leaning than other definitions (Burge and Lewis 2018b). ${ }^{10}$ This approach, also used in contemporary studies (Margolis 2020), defines Evangelicals by their theological beliefs, and locates Evangelism within Protestantism and views religion as an individual identity.

\footnotetext{
${ }^{10}$ The primary concern is that only counting Protestants who identify as Evangelical excludes other Christian denominations - for instance, Catholics, and Letter Day Saints (LDS) - who may identify also identify as Evangelical. However, it is important to note that the proportion of Catholics who identity as Evangelical in public opinion surveys are relatively small (Cassese 2020). Similarly, though some LDS members may also identify as Evangelical, the very small number of LDS respondents in public opinion surveys mean that their exclusion has not significantly biased the results of similar studies (Ayris 2020).
} 
A separate approach defines Evangelicals by the religious tradition that individuals belong to (Schmidt 2019). The RELTRAD method similarly focuses on intra-Protestant variations. However, perhaps the most glaring limitation especially relevant in the context of the current study is that, in the RELTRAD method, a respondents' race is not factored into these categorizations (Schmidt 2019). The RELTRAD method may therefore not be the most appropriate definition to take in studies such as this one, where the aim is to understand White Evangelical beliefs and behaviors. Because of my theoretical interest in understanding White Evangelical preferences for elite religiosity, I therefore opt for the former method. Crucially, this method allows for the inclusion of race into my religious classification scheme, and as noted in the previous paragraph, has also been used to study White Evangelicals in a number of contemporary studies. Nonetheless, it is important to be aware of the limitations of my chosen definition for the purposes of conducting a transparent investigation.

To test these hypotheses, data are taken from Wave 61 of Pew's American Trends Panel (ATP). The ATP is a nationally representative, probability based online panel of noninstitutionalized persons aged 18 or over living in any of the 48 contiguous US states, as well as Alaska or Hawaii. Wave 61 of the ATP was conducted on behalf of Pew by the polling company Ipsos from February 4, to February 20, 2020. Altogether, $\mathrm{N}=6,395$ ATP panelists completed Wave 61. Survey weights were constructed by Pew for the online sample, which are used here so that results are generalizable to the US adult population.

\section{Dependent Measures}

The dependent measure to test $\mathbf{H 1}$ is an index constructed from three measures that asks respondents how important it is to have a President who exhibits a number of qualities 
(Cronbach's $\alpha=.78) .{ }^{11}$ These are i) having a President who shares my religious beliefs, ii) having a President who has strong religious beliefs, and iii) having a President who stands up for my religious beliefs. The items are all measured on four-point ordinal scale, with possible responses ranging between $1=$ "not at all important," to $4=$ "very important." The three items are summed and then averaged to form a composite index. The computed index is scaled to range between 0 and 1 .

The focal dependent measure to test $\mathbf{H} \mathbf{2}$ is a four-point ordinal item that asks respondents how religious they think Trump is, with possible responses ranging between $1=$ "not at all religious," to 4 = "very religious." I also include measures for evaluations of the religiosity of a number of Democratic and Republican elites beyond Trump, including Bernie Sanders, Elizabeth Warren, Joe Biden, Pete Buttigieg, and Mike Pence.

To test H3, I use a dichotomous item that asks respondents whether they consider themselves to be a minority because of their religious beliefs. Respondents who consider themselves to be a minority because of their religious beliefs are coded as 1, and those who do not as 0 .

Lastly, the dependent measure to test $\mathbf{H 4}$ is a four-point categorical item that asks which statement comes closest to a respondent's view about god's role in the 2016 election, even if none are exactly right. The four statements are: i) God chose Trump to be President because God approves of Trump's policies, ii) Trump's election must be part of god's plan but doesn't necessarily mean that God approves of Trump's policies, iii) god does not get involved in elections, and iv) I do not believe in God.

\section{Independent Measures}

\footnotetext{
${ }^{11}$ As well as exhibiting an acceptable score for internal reliability, the three items load onto a single factor with an eigenvalue $=1.506$, suggesting that they are measuring the same latent concept (i.e., elite religiosity).
} 
Religion Measures. Denomination and religiosity are both used to measure religion.

Religious denominations are coded using a classification scheme outlined by the Public Religion Research Institute (PRRI) using 8 categories: White Evangelical Protestant, Black Protestant, Hispanic Protestant, White Catholic, Hispanic Catholic, other Christian, nonChristian, and the religiously unaffiliated, with White mainline Protestants serving as the reference category. ${ }^{1213}$

Religiosity is measured with three items. ${ }^{14}$ The first is a four-point ordinal item that asks how important religion is to a respondent, with possible responses ranging between $1=$ "not at all important," to $4=$ "very important." The second is a six-point ordinal item that asks how often a respondent attends religious service, with possible responses ranging between $1=$ "never," to $6=$ "more than once a week." The third item is a seven-point ordinal item that asks how often a respondent prays, with possible responses ranging between $1=$ "never," to 7 = "several times a day."

Controls. In addition to the measures outlined above, models are also estimated with a number of socio-political, demographic, and structural covariates. Respondents with a partisan or leaned partisan affiliation with the Republican Party are coded 1, and those with a partisan or leaned partisan affiliation with the Democratic Party as $0 .{ }^{15}$ Ideology is a fivepoint ordinal item ranging between $1=$ "very liberal," to $5=$ "very conservative." Age is a

\footnotetext{
${ }^{12}$ A comprehensive elucidation of the PRRI coding scheme is presented in section A1 of the SI file.

${ }^{13}$ As aforenoted, one concern related to my chosen definition of Evangelism is the omission of LDS and Catholic respondents who identify as Evangelical Christians. To assess whether the omission of Evangelical Catholics and LDS member biases the White Evangelical Protestant coefficient, I also estimate models with a modified White Evangelical measure that includes these denominations. Results of the models using this alternative measure do not differ substantively from those in the main paper, and are presented in section $\mathbf{A} 2$ of the SI file.

${ }^{14}$ The three items exhibit a high score for internal reliability (Cronbach's $\alpha=.87$ ).

${ }^{15}$ While desirable, Pew datasets do not contain the standard 7-point scale for party ID.
} 
four-point ordinal item ranging between $1=$ "18-29," to $4=$ " $65+. " 16$ Male are coded as 1 and females as 0 . Education is a six-point ordinal item ranging between $1=$ "less than high school," to 6 = "postgraduate." Lastly, respondents who reside in the South are coded 1, and those who reside elsewhere as 0 . Unless noted, all variables are z-transformed to obtain standardized coefficient estimates.

\section{Results}

\section{Preferences for Elite Religiosity}

H1 posited that White Evangelicals would exhibit strong preferences for elite religiosity. To test this possibility, the elite religiosity index was regressed against the religious identity and religiosity measures, as well as the set of covariates. The results are presented below in Figure 1. Points to the right of the $x$ axis in Figure 1 indicate a positive relationship between a given variable of interest and the dependent measure, or stronger preferences for elite religiosity. Conversely, points to the left of the $\mathrm{x}$-axis indicate a negative relationship, or weaker preferences for elite religiosity.

As evidenced by Figure 1, the White Evangelical coefficient is positively associated with preferences for elite religiosity $(\beta=.023, p=<.001)$. The magnitude of this effect is also substantial, with the size of the standardized coefficient being larger than that for any other PRRI religious classification. Beyond White Evangelicals, other PRRI classifications that exhibit strong preferences for elite religiosity include Black Protestants $(p=<.001)$, Hispanic Protestants $(p=<.001)$, and "other" Christians $(\mathrm{p}=<.05)$. By contrast, the religiously unaffiliated exhibit markedly weaker preferences for elite religiosity $(p<.001)$.

\footnotetext{
${ }^{16}$ Age is modelled as an ordinal covariate. Modelling age by generational cohort does not affect the significance and direction of the results presented here.
} 
These results thus lend weight to the hypothesis that White Evangelicals have strong preferences for having a President who is highly religious.

\section{Figure 1: OLS Estimates of Preferences for Elite Religiosity}

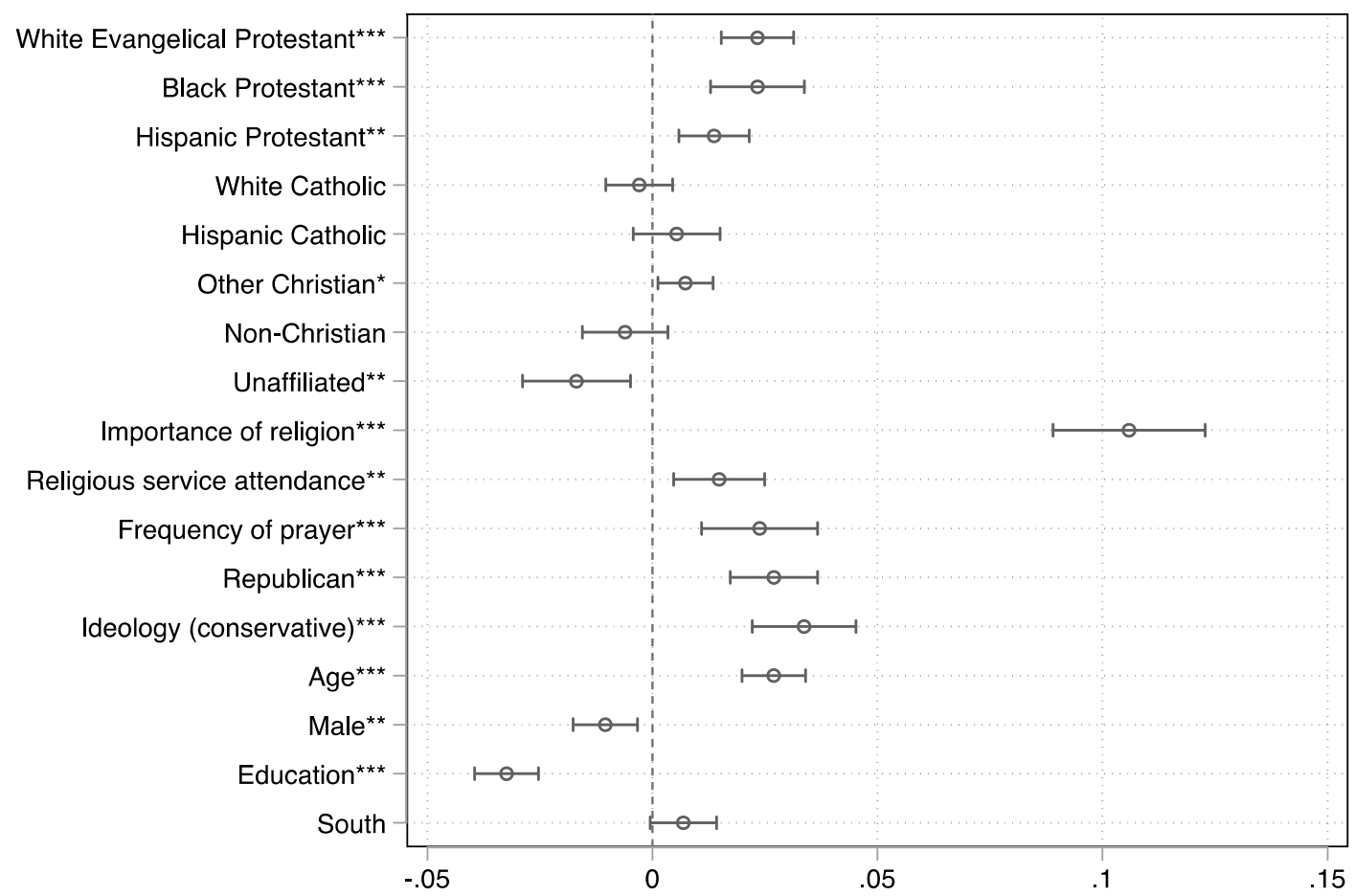

Notes: Points represent the size of each standardized OLS coefficient. The capped lines are 95 percent confidence intervals. Data are weighted. Asterisks indicate a statistically significant coefficient $(* p<.05 * * p<.01 * * * p<.001)$. Full estimates presented in section $\mathbf{A 3}$ of the SI file.

Source: American Trends Panel (Wave 61).

Beyond the religion measures, we also find significant effects on preferences for elite religiosity through all of the measures for respondent religiosity. Importance of religion is, by some considerable margin, the strongest correlate of preferences for elite religiosity, with the size of the standardized coefficient being four times larger than that of the White Evangelical coefficient $(\beta=.105, p=<.001)$. High frequency of religious service attendance $(p=<.01)$ and prayer are likewise associated with strong preferences for elite religiosity, though it is 
important to note that frequency of religious activities appear to matter less much than the subjective importance of religion. ${ }^{17}$

As a robustness check to assess whether the White Evangelical coefficient was a substantive correlate of all sub-indices used to compute the elite religiosity index, I regress the same set of variables against each of the three items for religiosity. In these models, I find that the White Protestant coefficient is significantly associated with preferences for a President who shares the same religious beliefs, and preferences for a President who stands up for the same religious beliefs (all $p=<.001$ ). However, being a White Evangelical appears to have little substantive impact on individual preferences for a President with strong religious beliefs. Full model estimates from these alternative models are presented in section A4 of SI file.

\section{Evaluations of Elite Religiosity}

Having established that White Evangelicals exhibit strong preferences for elite religiosity, I next to turn to test the extent to which they evaluate Trump as being highly religious. $\mathbf{H 2}$ posited that White Evangelicals would not evaluate Trump as being particularly religious. To test this possibility, the four-point ordinal item for evaluations of Trump's religiosity was regressed against the religion and religiosity measures, as well as the set of covariates. The results are presented below in Figure 2. Points to the right of the $x$ axis indicate a positive relationship between a given variable of interest and the dependent

\footnotetext{
${ }^{17}$ Though it is not my main focus here, Figure $\mathbf{1}$ also indicates a number of interesting effects on elite religiosity through the set of covariates. Republican partisanship $(p=<.0011)$ and political conservatism $(p=$ $<.001)$ are both positively associated with preferences for elite religiosity, as is age $(p<.001)$. Men appear to exhibit notably weaker preferences for elite religiosity $(p=<.01)$, as do the highly educated $(p=<.001)$. Despite being positively related to the dependent measure, the coefficient for Southern residency does not reach acceptable levels of statistical significance, a surprising find given the religious history of the South (Harvey 2016).
} 
measure, or a respondent evaluating that Trump is highly religious. Conversely, points to the left of the $x$ axis indicate a negative relationship, or the belief that Trump is irreligious. A

Figure 2: Ordered Probit Estimates for Evaluations of Trump's Religiosity

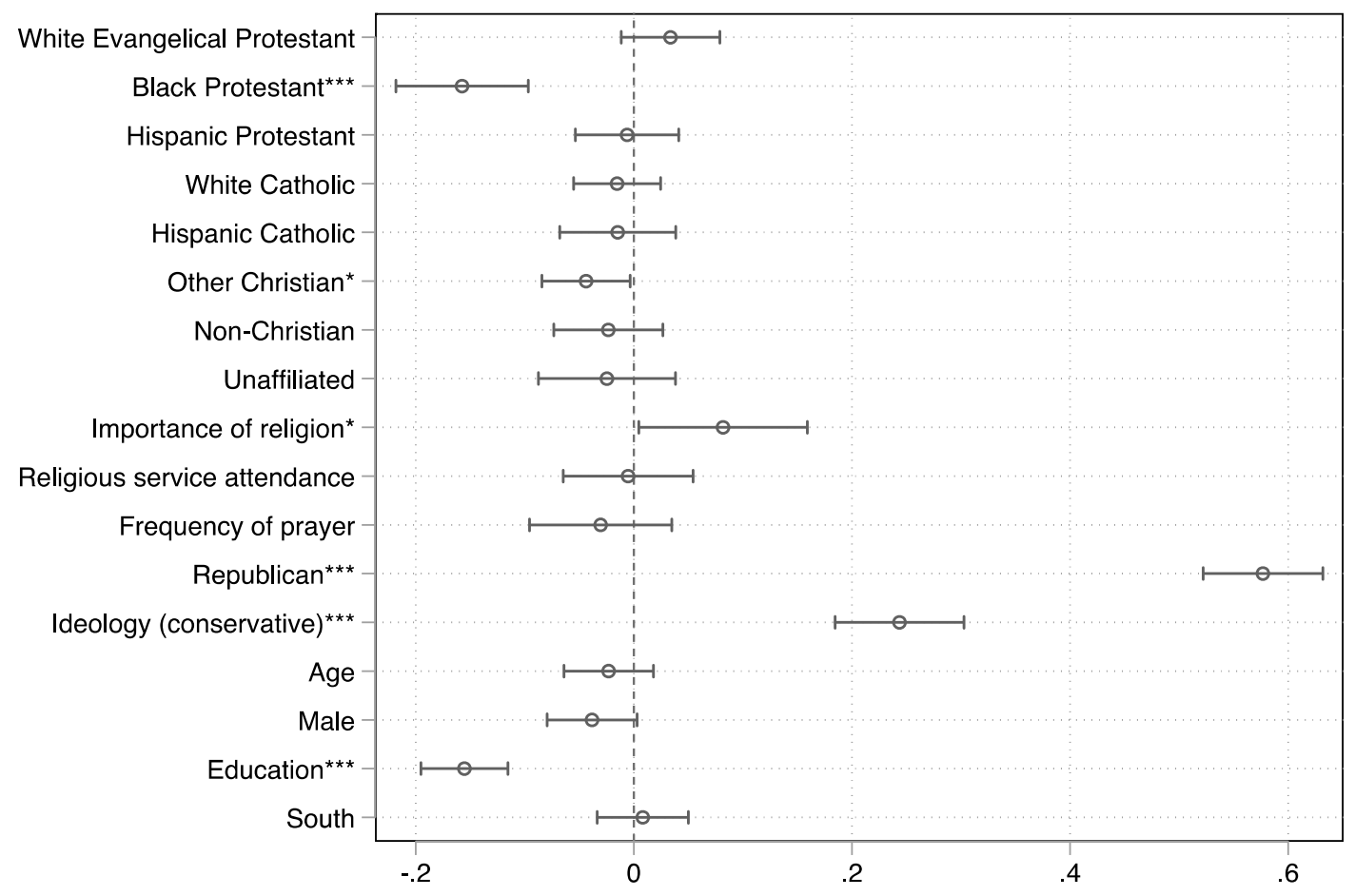

Notes: Points represent the size of each ordered probit coefficient. The capped lines are 95 percent confidence intervals. Data are weighted. Asterisks indicate a statistically significant coefficient $(* p<.05 * * p<.01 * * * p<.001)$. Full estimates presented in section $\mathbf{A 5}$ of the SI file.

Source: American Trends Panel (Wave 61).

As evidenced by Figure 2, the White Evangelical Protestant coefficient is positively related to the dependent measure, but nonetheless fails to exhibit conventional levels of statistical significance. This result indicates that being a White Evangelical has little impact 
on whether an individual perceives Trump to be religious, thus lending some weight to $\mathbf{H 2}{ }^{18}$ There are a number of possible explanations for the insignificant effect for the White Evangelical Protestant coefficient. One possibility is that White Evangelical Protestants do not exhibit robust preferences for any elites with particular strong religious beliefs. In this way, by testing for Trump's evaluations religiosity, the findings from Figure $\mathbf{2}$ are simply a substantive demonstration of the more generalized, weaker preferences for a President with particularly strong religious beliefs that were observed in my alternate models for $\mathbf{H 1}$ (see Model 3, Table A4 in the SI). However, another possibility is that White Evangelicals are largely indifferent to Trump's religiosity while they are concurrently able (and indeed do) evaluate other elites by their religiosity. This possibility would play into Whitehead et al.'s (2018) theory that perceptions of declining influence and impending minority status among White Christians were likely to outweigh any concerns about religiosity when it came to their specific evaluations of Trump.

To probe this possibility, it is necessary to quantify the extent to which White Evangelical Protestants are able to evaluate the religiosity of other elites. Usefully, Wave 61 of the ATP also asked the same question regarding the religiosity number of elites beyond Trump. If White Evangelical Protestants are largely indifferent to Trump's religiosity only, then we should expect to observe a consistent pattern of significant results when it comes to their evaluations of the religiosity of other elites.

Figure 3 presents the results of a series of models gauging evaluations of the religious of the major candidates for the 2020 Democratic Presidential nomination, as well as Mike Pence. For brevity, Figure 3 plots the White Evangelical coefficient only. Once again, points

\footnotetext{
${ }^{18}$ In fact, the only significant coefficients for religion are for Black Protestants $(\mathrm{p}<.001)$, and "other" Christians $(\mathrm{p}=<.05)$. Here, both of the coefficients are negatively associated with the dependent measure, indicating that Black Protestants and "other" Christians perceive Trump to be irreligious.
} 
to the right of the $x$ axis in Figure 3 indicate a positive relationship between the coefficient and the dependent measure, or an individual evaluating that a particular elite is highly religious. Conversely, points to the left of the $x$ axis indicate a negative relationship, or an individual evaluating that a particular elite is irreligious.

Figure 3: Ordered Probit Estimates of White Evangelical Evaluations of Rep/Dem

\section{Religiosity}

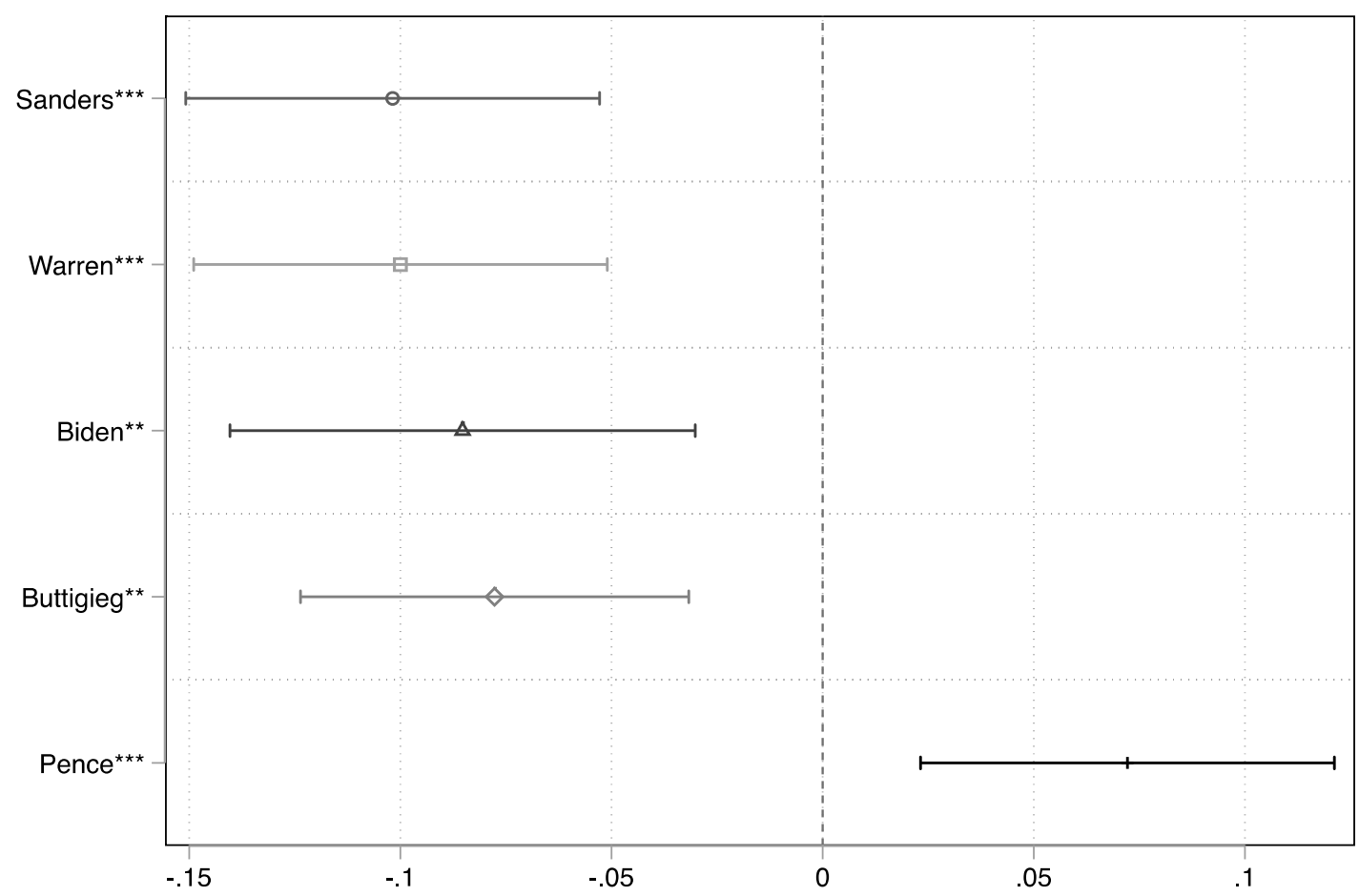

Notes: Points represent the size of the ordered probit coefficient (sorted by size) for White Evangelical Protestant identity in each model. The capped lines are 95 percent confidence intervals. Data are weighted. Asterisks indicate a statistically significant coefficient $(* p<.05 * * p$ $<.01 * * * p<.001)$. Full estimates presented in section $\mathbf{A 6}$ of the SI file.

Source: American Trends Panel (Wave 61).

As evidenced by Figure 3, White Evangelicals appear to have little difficulty in being able to evaluate the religiosity of elites other than Trump. The White Evangelical coefficient is negatively associated with evaluations of the religiosity of Bernie Sanders $(p=<.001)$, 
Elizabeth Warren $(p=<.001)$, Joe Biden $(p=<.01)$, and Pete Buttigieg $(p=<.01)$. In substantive terms, this means that White Evangelicals evaluate all of these Democratic elites as being irreligious. Conversely, the coefficient is positively associated with evaluations of the religiosity of Mike Pence ( $p=<.001)$, a non-Trump GOP elite. In sum, the results of Figure 3 provide strong evidence in favor of the theory that Trump is something of a unique case when it comes to White Evangelical evaluations of elite religiosity; they perceive a slew of Democratic elites as irreligious, whilst concurrently demonstrating that they are able to evaluate non-Trump Republicans as being religious.

\section{White Evangelicals as Religious Minorities}

I now turn to examine the extent to minority status perceptions shape evaluations of Trump. In order to understand whether minority status perceptions condition evaluations of Trump, it is first necessary to quantify the extent to which White Evangelicals consider themselves to be minorities as a consequence of their religious beliefs $(\mathbf{H 3})$. To test this possibility, the dichotomous item for perceptions of minority belief status was regressed against the religion and religiosity measures, as well as the set of covariates. For brevity, Figure 4 depicts the coefficient estimates for the eight respective PRRI classifications. Points to the right of the $x$ axis in Figure 4 indicate a positive relationship between a given variable of interest and the dependent measure, or a respondent considering themselves to be a minority because of their religious beliefs. Conversely, points to the left of the $x$ axis indicate a negative relationship, a respondent not considering themselves to be a minority as a consequence of their religious beliefs.

As evidenced by Figure 4, the White Evangelical coefficient is positively associated with the dependent measure $(\beta=.224, p=<.001)$. Notably, the size of the coefficient is larger than that for a number of other racial-religious groups who exhibit similar feelings, 
including Black Protestants $(p=<.001)$, and "other" Christians $(p=<.001)$. Only the religious unaffiliated $(p=<.001)$, and non-Christians $(p=<.001)$ appear to consider themselves minorities more than White Evangelicals, while White Catholics and Hispanic Catholics do not appear to consider themselves minorities as a consequence of their religious beliefs. The results from Figure 4 therefore provide robust evidence in favor of the hypothesis that White Evangelicals consider themselves to be a marginalized group as a result of the beliefs $(\mathbf{H 3})$.

\section{Figure 4: Probit Estimates for Minority Status Perceptions, by Religious Identity}

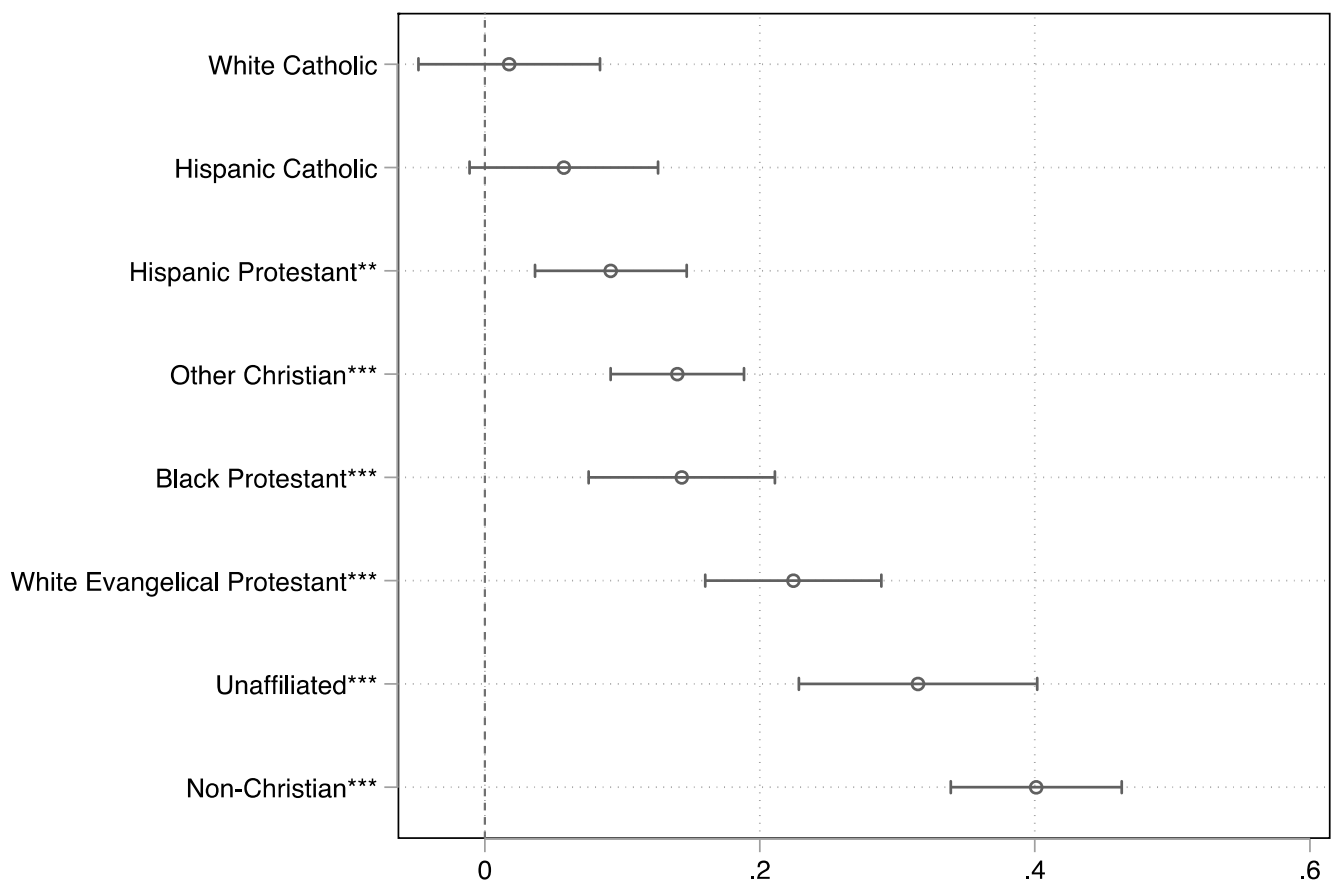

Notes: Points represent the size of each probit coefficient (sorted by size). The capped lines are 95 percent confidence intervals. Data are weighted. Asterisks indicate a statistically significant coefficient $(* p<.05 * * p<.01 * * * p<.001)$. Full estimates presented in section A7 of the SI file.

Source: American Trends Panel (Wave 61).

As a further assurance that White Evangelicals consider themselves to be a marginalized group, it is also worth considering whether they perceive that their beliefs are in 
conflict with an increasingly pluralistic society. To test this possibility, I estimate a further model gauging White Evangelical perceptions of whether their religious beliefs are in conflict with mainstream US culture. ${ }^{19}$ In this additional model, the White Evangelical Protestant coefficient is larger than that for other religious groups and is significant at the $p=$ $<.001$ level. The results of this additional model therefore provides us with further indication that White Evangelicals perceive themselves as being a marginalized group. Full estimates of the additional model are presented in section $\mathbf{A 8}$ of the $\mathbf{S I}$ file.

\section{Elections as Divine Outcomes}

Having established that White Evangelicals consider themselves minorities because of their religious beliefs, I finally turn to examine whether these beliefs condition perceptions of whether Trump's 2016 election was a divine outcome (H4). To test this possibility, the categorical dependent measure was regressed against the White Evangelical item, which was interacted with the dichotomous item for minority status perceptions. After estimating the multinomial probit model, I then use postestimation to graph two sets of results. The estimates of the postestimations are presented below in Figures 5 and $\mathbf{6}$.

I begin first with Figure 5. Figure 5 depicts the White Evangelical/not White Evangelical responses to each category of the dependent measure across levels of the minority status perceptions measure. The graph therefore provides an indication of the relative effects of being a White Evangelical on the dependent measure as minority status perceptions become more salient. As indicated by the left panel in Figure 5, the beliefs on God's role in Trump's election among respondents who are not White Evangelical Protestants appear to change little as perceptions of minority status become more salient.

\footnotetext{
${ }^{19}$ This measure is a four-point ordinal item, with possible responses ranging between 1 = "no conflict at all," to 4 = "a great deal of conflict."
} 
Moving onto the right panel, however, we see that increases in the salience of minority status perceptions are associated with much greater belief change among White Evangelicals, with the most precipitous changes evidenced among those who are most ambivalent about God's role in Trump's election. As evidenced here, the predicted probability of a White Evangelical respondent thinking that God does not get involved in elections declines by 18 points. Figure 5 thus gives us a first indication that minority status perceptions are shaping beliefs about God's role in Trump's election, and that these effects are especially salient for White Evangelicals relative to other individuals.

Figure 5: Beliefs on God's Role in Trump's Election as a Function of White Evangelical Identity, by Minority Status Perceptions.

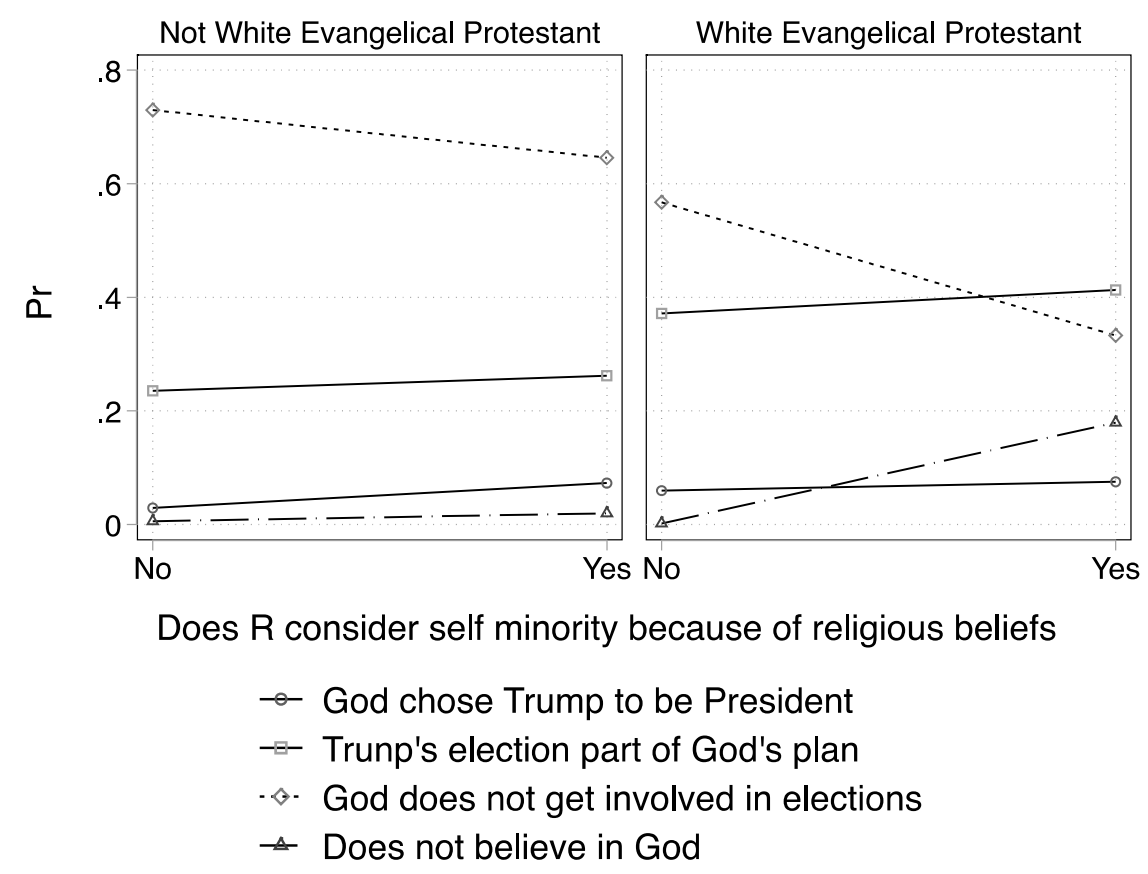

\footnotetext{
Notes: Points represent the predicted probability of a White Evangelical/not White Evangelical respondent response to each category of the multinomial dependent measure at each level of the minority status perception item. Estimates based on a multinomial probit model controlling for the interaction between White Evangelical Protestant item and minority-status perception item. All other variables in model hold constant or at their respective mean values. Full model estimates presented in section A9 of the SI file.
}

Source: American Trends Panel (Wave 61). 
Figure 6, the primary figure of interest in relation to my test of $\mathbf{H 4}$, displays the marginal effect of being a White Evangelical Protestant on beliefs of whether Trumps election was a divine outcome by their religious minority status perceptions. If minority status perceptions do condition White Evangelical Protestants' beliefs about God's role in Trump's election, de minis, then we should expect to see substantive changes and significant in the probability of each outcome as minority-status perceptions become more salient.

Figure 6: Marginal Effect of Being a White Evangelical Protestant on Beliefs in God's Role in Trump's Election, by Minority-Status Perception

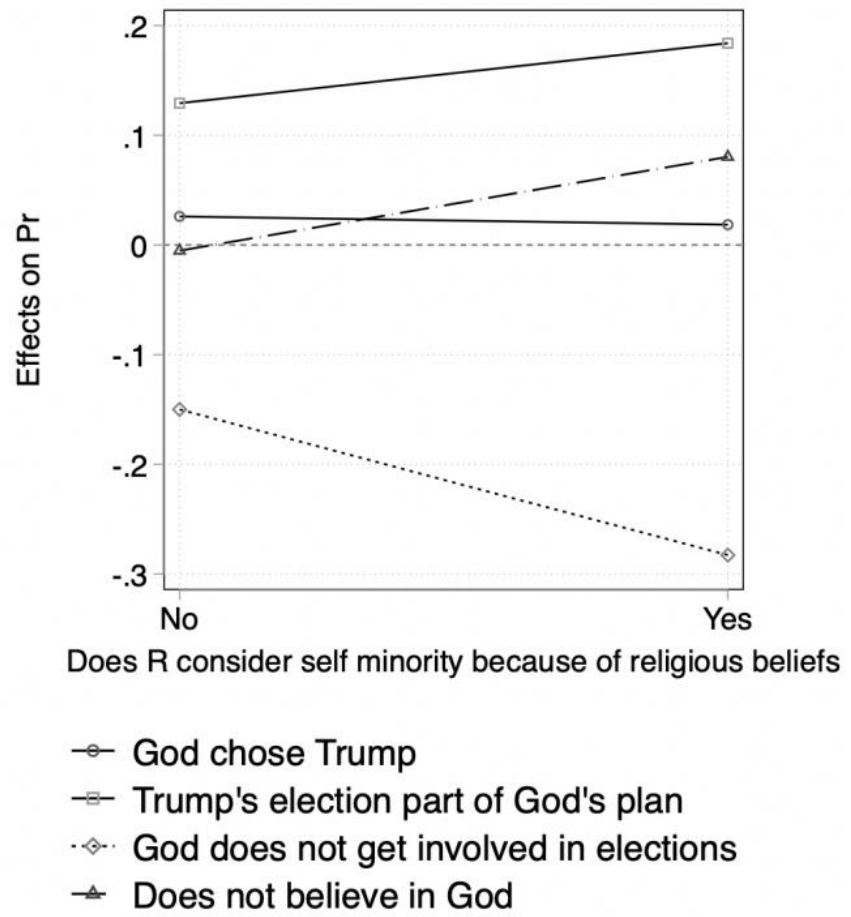

Notes: Points represent the marginal effect of being a White Evangelical Protestant on each outcome by minority-status perceptions. Estimates based on a multinomial probit model controlling for the interaction between White Evangelical Protestant item and minority-status perception item. All other variables in model hold constant or at their respective mean values. Full model estimates presented in section A9 of the SI file.

Source: American Trends Panel (Wave 61). 
Do minority status perceptions condition White Evangelical Protestant beliefs about God's role in Trump's election? I begin first with the pattern of insignificant results. When it comes to the belief that God chose Trump to be President, increases in the salience of minority status perceptions appear to do little to condition White Evangelical Protestants' responses. We also see what appears to be large change in the predicted probability for the "does not believe in God response," perhaps suggesting a conditioning effect. However, the effects of minority status perceptions on the White Evangelical response do not reach the acceptable $p=<.05$ level of statistical significance.

By contrast, the most substantive changes in the predicted probability of each response to the categorical measure come from those who are more ambivalent in their views on God's role in Trump's election. ${ }^{20}$ For instance, among those who do not consider themselves to be minorities because of their religious beliefs, being a White Evangelical Protestant is associated with an 8-point increase in the predicted probability of a respondent thinking that Trump's election is part of God's plan $(p=<.001)$. Contrastingly, among those who exhibit the most salient perceptions of minority-status, being a White Evangelical is associated with an 18-point increase in the predicted probability of a respondent thinking the same thing $(p=<.001)$.

We see an even larger change when it comes to the belief that God does not get involved in elections. Among those who do not consider themselves minorities as a result of their religious beliefs, White Evangelicals are 14 points less likely to believe that God does not get involved in elections $(p=<.001)$. However, among those who do consider themselves minorities, White Evangelicals become 28 points less likely to believe that God does not get involved in elections $(p=<.001)$. In sum, these findings suggests that minority status

\footnotetext{
${ }^{20}$ That is, among those who either believe that Trump's election is part of God's plan, or who believe that God does get involved in elections.
} 
perceptions do condition White Evangelical beliefs about God's role in Trump's election. However, it is important to qualify that this movement is only significant for those who are more ambivalent in their views on God's role Trump's election.

\section{Discussion}

Trump's robust and unwavering support among White Evangelicals has received extensive attention from commentators and scholars alike - a level of attention not unwarranted given the interesting contradiction between Trump's seeming lack of religiosity and the degree to which White Evangelicals coalesced around his candidacy. Trump enjoyed consistently high levels of favorability among White Evangelicals throughout his Presidency (Martinez and Smith 2016; Smith 2020) even as his favorability among the wider American public remained markedly lower overall (FiveThirtyEight 2021). This paper explores whether elite religiosity matters to White Evangelicals in order to better answer the question of why so many of them support Trump despite his well-publicized personal transgressions and seemingly irreligiosity.

These results contribute to our understanding of White Evangelical attitudes towards elite religiosity in three important ways. First, the findings extend our existing understanding of White Evangelicals preferences for elite religiosity. Despite the burgeoning number of studies highlighting the contradiction between Trump's irreligiosity and distinctly "unChristian" behavior and his strong support among White Evangelicals (Whitehead et al. 2018; Wehner 2019; Ayris 2020; Whitehead and Perry 2020), the extent to they had strong preferences for having a President who was religious was unclear. However, given the scholarship on prior studies the effects religious identity on evaluations of elites (Castle et al. 2017; Schmidt and Miles 2017), we nonetheless had reason to suspect that religious adherents would exhibit strong, generalized preferences for elite religiosity. The findings 
from Figure 1 thus go some way to answering this question by demonstrating that White Evangelicals do exhibit relatively strong, generalized preferences for having a President who exudes religiosity and is willing to stand up for their religious group interests.

Second, the finding regarding White Evangelical evaluations of Trump's religiosity underscores an important point. White Evangelicals appear to know and acknowledge that Trump isn't particularly religious. However, they are able to evaluate the perceived religiosity or irreligiosity of a slate of Democratic and Republican elites beyond Trump. This finding suggests that Trump is a unique case when it comes to White Evangelical evaluations of the religiosity of elites: instead of projecting their beliefs onto Trump, and thereby supporting him because of his perceived religiosity, White Evangelicals support him despite his lack of religiosity.

This finding brings to mind an interesting literature on projection heuristics. While much of the projection heuristics scholarship focuses on ideological projection and not religion (Lerman and Sadin 2016), the mechanism (or lack thereof in this case) remains largely the same; individuals are prone to overestimate (i.e., project) the probability of sharing a characteristic with another individual (Ross et al. 1977). When applied as a model for elite evaluations, projection is thus moderated by the extent to which individuals are linked to the elite by a shared characteristic. Therefore, if White Evangelicals do project their religious beliefs onto Trump, then we ought to have expected to see a significant effect through the White Evangelical coefficient on evaluations of Trump's religiosity in Figure 2. ${ }^{21}$ While statistically insignificant, this finding is noteworthy because it goes some way to answering the contradiction that has piqued the interests of contemporary scholarship at the

\footnotetext{
${ }^{21}$ If religion does not shape evaluations of Trump's religiosity it is worth considering what does. Looking at Figure 2, party ID dominates the religion and religiosity measures, suggesting that socio-political beliefs are doing much of the work in driving evaluations of Trump religiosity - a finding congruous with scholarship on the power of partisanship on elite evaluations (Bartels 2002; Hayes 2005).
} 
intersection of politics and religion. The answer is that White Evangelicals exhibit strong, generalized preferences for elite religiosity. But in the specific case of Trump's religiosity, they are notably ambivalent.

Lastly, these findings must be considered alongside a noteworthy trend from the public opinion data - the belief among many White Evangelicals that Trump was ordained by God to be President. If White Evangelicals do not evaluate Trump as being particularly religious, then why would 73 percent of them believe that God played a role in his election? Consistent with extant theorizing in the religious psychology scholarship (Ysseldyk et al. 2011), I hypothesized that religious identity threats would condition White Evangelicals' beliefs about God's role in Trump's election. Drawing on contemporary debates in the Christian nationalism scholarship (Whitehead et al. 2018), I similarly posited that White Evangelicals believed that Trump chose God to arrest the decline of Christian America. These beliefs are important because they are examples of coping appraisal mechanisms that individuals might adopt when encountering threats to their religious identities (Ysseldyk et al. 2011).

Largely in line with my expectations, I found that perceptions of minority status $d o$ condition White Evangelical beliefs regarding God's role in Trump's election. While these perceptions did little to condition to those whose views were the most crystalized (i.e., nonbelievers those and who thought Trump was directly chosen by God), much greater movement was observed when it came to those whose beliefs were ambivalent about Trump's election as a divine outcome. Here, it was found that perceptions of minority status increased the probability of a White Evangelical believing that Trump's election was part of God's plan. We also saw that these perceptions were associated with concurrent declines in the probability of White Evangelicals thinking that God does not get involved in elections. 
This finding is important because it offers a rationale for why White Evangelicals not only support Trump electorally (Margolis 2020), but also think he was chosen by God to President. The findings concerning the salience of identity threats on conditioning White Evangelical beliefs also provides an additional explanation for why evaluations Trump's religiosity might not have mattered when it came to their vote choice in 2016. Namely, because Trump's invocation of the decline of White Christian America proved effective in activating religious identity threat in a way that led to White Evangelicals to coalesce around his candidacy. In this way, Trump's ability to articulate White Evangelicals' fears about the declining influence of Christianity overrode any lingering concerns about his religiosity.

\section{Limitations and Future Directions}

It is also important to point to the limitations of the current study, as well as potential avenues for future research. One limitation of the current study is that I am not able to account for the potential effects of elite religious cues in shaping White Evangelical responses to the ATP measures. Elite cues are a powerful heuristic that shape individual beliefs and behaviors. Therefore, the manner in which elites such as Trump use and deploy elite religious cues ought to have noteworthy effects on White Evangelical evaluations of his religiosity. As noted in the literature review, Trump's failure to name a single bible passage give us reason to doubt whether his efforts they have proved effective in convincing White Evangelicals about his religiosity. In this way, ineffective deployment of covert religious cues may explain why White Evangelicals do not evaluate Trump as being particularly religious. Future research should look to the effects of similar cues in shaping evaluations of elite religiosity. Experimental research designs would allow for the investigation of the impact of these cues across a variety of similar measures to those used in this paper. 


\section{References}

Achen, C.H. and Bartels, L.M., 2017. Democracy for realists: Why elections do not produce responsive government. Princeton, NJ: Princeton University Press.

Albertson, B.L., 2015. Dog-whistle politics: Multivocal communication and religious appeals. Political Behavior, 37(1), pp.3-26.

Alexander, N.H., 2020. Latino Evangelicals: How Their Multiple Identity Influences Their Political Preferences (Doctoral dissertation, The Claremont Graduate University).

Ayris, A., 2020. “They'd Vote Against Jesus Christ Himself”: Trump's “White Evangelicals," the Construction of a Contested Identity, and the Need for a New Narrative. Journal of Church and State.

Bartels, L.M., 2002. Beyond the running tally: Partisan bias in political perceptions. Political behavior, 24(2), pp.117-150.

Blair, L., 2016. Ted Cruz Quotes Scripture, Thanks God and 'Courageous Conservatives' After Iowa Victory. The Christian Post, February 2. Available: https://www.christianpost.com/news/ted-cruz-quotes-scripture-thanks-god-iowacaucus.html

Branscombe, N.R., Ellemers, N., Spears, R. and Doosje, B., 1999. The context and content of social identity threat. Social identity: Context, commitment, content, pp.35-58.

Burge, R.P. and Lewis, A.R., 2018a. Measuring Evangelicals: Practical Considerations for Social Scientists. Politics \& Religion, 11(4).

---. 2018b. Measuring Evangelicals: Practical Considerations for Social ScientistsCORRIGENDUM. Politics and Religion, 11(4), pp.920-925.

Calfano, B.R. and Djupe, P.A., 2009. God talk: Religious cues and electoral support. Political Research Quarterly, 62(2), pp.329-339. 
Campbell, D.E., Layman, G.C., Green, J.C. and Sumaktoyo, N.G., 2018. Putting politics first: The impact of politics on American religious and secular orientations. American Journal of Political Science, 62(3), pp.551-565.

Campbell, D.E. and Monson, J.Q., 2008. The religion card: Gay marriage and the 2004 presidential election. Public Opinion Quarterly, 72(3), pp.399-419.

Cassese, E.C., 2020. Straying from the flock? A look at how Americans' gender and religious identities cross-pressure partisanship. Political Research Quarterly, 73(1), pp.169183.

Castle, J.J., 2019. New fronts in the culture wars? Religion, partisanship, and polarization on religious liberty and transgender rights in the United States. American Politics Research, 47(3), pp.650-679.

Castle, J.J., Layman, G.C., Campbell, D.E. and Green, J.C., 2017. Survey experiments on candidate religiosity, political attitudes, and vote choice. Journal for the Scientific Study of Religion, 56(1), pp.143-161.

Egan, P.J., 2020. Identity as dependent variable: How Americans shift their identities to align with their politics. American Journal of Political Science, 64(3), pp.699-716.

Feuer A., 2018. What We Know About Trump's \$130,000 Payment to Stormy Daniels. The New York Times, August 27. Available:

https://www.nytimes.com/2018/08/27/nyregion/stormy-daniels-trump-payment.html

FiveThrityEight, 2021. How popular is Donald Trump? Available: https://projects.fivethirtyeight.com/trump-approval-ratings/?cid=rrpromo

Frank, T., 2004. What's the matter with Kansas?: How conservatives won the heart of America. New York City, NY: Henry Hoult and Company.

Gorski, P., 2019. Why evangelicals voted for Trump: A critical cultural sociology. In Politics of meaning/meaning of politics (pp. 165-183). Palgrave Macmillan, Cham. 
Green, J.C., Rozell, M.J. and Wilcox, C. eds., 2000. Prayers in the precincts: The Christian right in the 1998 elections. Washington D.C.: Georgetown University Press.

Hackett, C. and Lindsay, D.M., 2008. Measuring evangelicalism: Consequences of different operationalization strategies. Journal for the Scientific Study of Religion, 47(3), pp.499-514.

Haider-Markel, D.P., 2007. Representation and backlash: The positive and negative influence of descriptive representation. Legislative Studies Quarterly, 32(1), pp.107-133.

Harvey, P., 2016. Christianity and race in the American South: A history. Chicago, IL: University of Chicago Press.

Hayes, D., 2005. Candidate qualities through a partisan lens: A theory of trait ownership. American Journal of Political Science, 49(4), pp.908-923.

Hunter, J.D., 1992. Culture wars: The struggle to control the family, art, education, law, and politics in America. New York City, NY: Avalon Publishing.

Jones, R.P., 2016. The end of white Christian America. New York City, NY: Simon and Schuster.

Keenan J. P., and Pereira, I., 2020. For many white evangelicals, the Supreme Court makeup solidifies their support for President Trump. ABC, October 16. Available: https://abcnews.go.com/Politics/white-evangelicals-supreme-court-makeup-solidifiessupport-president/story?id=73153818

Kinnvall, C., 2004. Globalization and religious nationalism: Self, identity, and the search for ontological security. Political psychology, 25(5), pp.741-767.

Layman, G., 2001. The great divide: Religious and cultural conflict in American party politics. New York City, NY: Columbia University Press.

Lerman, A.E. and Sadin, M.L., 2016. Stereotyping or projection? How white and black voters estimate black candidates' ideology. Political Psychology, 37(2), pp.147-163. 
Margolis, M.F., 2018. From politics to the pews: How partisanship and the political environment shape religious identity. Chicago, IL: University of Chicago Press.

---. 2020. Who Wants to Make America Great Again? Understanding Evangelical Support for Donald Trump. Politics \& Religion, 13(1).

Martí, G., 2019. The unexpected orthodoxy of Donald J. Trump: White evangelical support for the 45th President of the United States.

Martinez, J., and Smith, G. A., 2016. How the faithful voted: A preliminary 2016 analysis. Washington D.C.,: Pew Research Center.

McDermott, M.L., 2009. Religious stereotyping and voter support for evangelical candidates. Political Research Quarterly, 62(2), pp.340-354.

McLaughlin, B. and Wise, D., 2014. Cueing God: Religious cues and voter support. Politics \& Religion, 7(2), pp.366-394.

Merritt, 2016. Trump's Bible fail. The Atlantic, April 15. Available:

\section{https://www.theatlantic.com/politics/archive/2016/04/trumps-bible-fail/478425/}

Mooney, M. J., 2019. Trump's apostle. Texas Monthly, August. Available: https://www.texasmonthly.com/articles/donald-trump-defender-dallas-pastor-robertjeffress/

Mouw, T. and Sobel, M.E., 2001. Culture wars and opinion polarization: the case of abortion. American Journal of Sociology, 106(4), pp.913-943.

Olson, L.R. and Warber, A.L., 2008. Belonging, behaving, and believing: Assessing the role of religion on presidential approval. Political research quarterly, 61(2), pp.192-204.

Popkin, S.L., 2020. The reasoning voter: Communication and persuasion in presidential campaigns. Chicago, IL: University of Chicago Press.

Posner, S., 2020. Unholy: Why white evangelicals worship at the altar of Donald Trump. Random House. 
Putnam, R.D., Campbell, D.E. and Garrett, S.R., 2012. American grace: How religion divides and unites us. New York City, NY: Simon and Schuster.

Reed, R., 2020. For God and Country: The Christian Case for Trump. Simon and Schuster.

Scala, D.J., 2020. Polls and Elections: The Skeptical Faithful: How Trump Gained Momentum among Evangelicals. Presidential Studies Quarterly, 50(4), pp.927-947.

Schildkraut, D.J., 2017. White attitudes about descriptive representation in the US: The roles of identity, discrimination, and linked fate. Politics, Groups, and Identities, 5(1), pp.84-106.

Schmidt, W. and Miles, M.R., 2017. Religious identity and descriptive representation. Politics \& Religion, 10(1), pp.186-221.

Schwadel, P., 2017. The Republicanization of evangelical Protestants in the United States: An examination of the sources of political realignment. Social science research, 62, pp.238-254.

Smidt, C.E., 2019. Reassessing the concept and measurement of evangelicals: The case for the RELTRAD approach. Journal for the Scientific Study of Religion, 58(4), pp.833853.

Smith, G. A., 2020. White Christians continue to favor Trump over Biden, but support has slipped. Washington D.C.,: Pew Research Center.

Tajfel, H., and Turner. J., 1979. An Integrative Theory of Intergroup Conflict. In The Social Psychology of Intergroup Relations, ed. Austin, W. E., and Worchel, S. Monterey, CA: Brooks/Cole, 33-47.

Weber, C. and Thornton, M., 2012. Courting Christians: How political candidates prime religious considerations in campaign ads. The Journal of Politics, 74(2), pp.400-413.

Wehner, P., 2019. The Deepening Crisis in Evangelical Christianity. The Atlantic. 
Wellman Jr, J.K. and Tokuno, K., 2004. Is religious violence inevitable?. Journal for the Scientific Study of Religion.

Whitehead, A.L. and Perry, S.L., 2020. Taking America Back for God: Christian Nationalism in the United States. New York City, NY: Oxford University Press.

Whitehead, A.L., Perry, S.L. and Baker, J.O., 2018. Make America Christian again: Christian nationalism and voting for Donald Trump in the 2016 presidential election. Sociology of Religion, 79(2), pp.147-171.

Ysseldyk, R., Matheson, K. and Anisman, H., 2010. Religiosity as identity: Toward an understanding of religion from a social identity perspective. Personality and Social Psychology Review, 14(1), pp.60-71.

Ysseldyk, R., Matheson, K. and Anisman, H., 2011. Coping with identity threat: The role of religious orientation and implications for emotions and action intentions. Psychology of Religion and Spirituality, 3(2), p.132.

Zimmerman, J., 2009. Whose America?: Culture wars in the public schools. Cambridge, MA: Harvard University Press. 
Supplemental Information for Does it matter if the President isn't pious? White Evangelicals and elite religiosity in the Trump era

A3: Full Model Estimates for Preferences for Elite Religiosity

A4: Alternate Model Specification for Preferences for Elite Religiosity

A5: Full Model Estimates for Evaluations of Trump's Religiosity

A6: Full Model Estimates for Evaluations of Rep/Dem Elite Religiosity

A7: Full Model Estimates for Minority Status Perceptions

A8: Additional Models for Marginalized Group Perceptions 


\section{A1: Religion Classification Scheme}

In this section, I outline the religious classification scheme used in the main paper. Because of my theoretical interest in understanding White Evangelical preferences for elite religiosity, I require a religious classification scheme that allows for the inclusion of race. As noted in the main paper, this already precludes me from using classification methods such as RELTRAD. Therefore, I defer to the method outlined by Burge and Lewis (2018a), where White Evangelicals are defined as Protestant adherents who identify subjectively as "born again" or Evangelical Christians. With this definition in mind, I now turn to outline my coding scheme.

For my specific coding scheme, I defer to the classifications outlined by the Public Religion Research Institute (PRRI) in their public opinion surveys of religious attitudes. The PRRI scheme outlines nine different religious classifications that allow for the inclusion of race. These classifications are: White mainline Protestant, White Evangelical Protestant, Black Protestant, Hispanic Protestant, White Catholic, Hispanic Catholic, “other” Christian, non-Christian, and the religiously unaffiliated. With this classification scheme in mind, I construct a total of eight variables for religion, with White mainline Protestants serving as the base category.

White Evangelical Protestants are coded as any White Protestant respondent who also considers themselves a "born again" or Evangelical Christian (13.08\% of the sample). The remaining Protestant categories are non-Hispanic Black Protestant (9.35\%), and Hispanic Protestant (3.17\%). Catholics are broken down by White Catholic (10.74\%) and Hispanic Catholic (6.58\%). “Other Christians," include Latter Day Saints (1.32\%), Orthodox Christians (0.35\%), Black Catholics (0.45\%), and Protestants or Catholics of any other race (2.25\%). Any respondents who identified their religion as Jewish (4.76\%), Muslim (0.61\%), Buddhist $(0.60 \%)$, Hindu $(0.61 \%)$, or “other" $(2.17 \%)$ are collapsed into a single measure for 
"non-Christian." Lastly, the religiously unaffiliated include atheists (6.21\%), agnostics (5.97\%), and those who do not identity with any particular religion (17.20\%) (Hackett et al. 2015). Accordingly, any respondents who met this definition were collapsed into a single measure of "unaffiliated" status. A sample breakdown using the PRRI classification scheme is presented below in Table A1.

Table A1: Sample Breakdown by Religious Classification

\begin{tabular}{lc}
\hline \multicolumn{1}{c}{ Category } & \% of Sample \\
\hline White mainline Protestant & $13.08 \%$ \\
\hline White Evangelical Protestant & $14.50 \%$ \\
\hline Black Protestant & $9.35 \%$ \\
\hline Hispanic Protestant & $3.17 \%$ \\
\hline White Catholic & $10.74 \%$ \\
\hline Hispanic Catholic & $6.58 \%$ \\
\hline Other Christian & $4.40 \%$ \\
\hline Non-Christian & $8.80 \%$ \\
\hline Unaffiliated & $29.38 \%$
\end{tabular}

Notes: Weighted estimates.

Source: American Trends Panel (Wave 61).

\section{References}

Hackett, C., Stonawski, M., Potančoková, M., Grim, B.J. and Skirbekk, V., 2015.

The future size of religiously affiliated and unaffiliated populations.

Demographic research, 32, pp.829-842. 


\section{A2: Alternate Classification Scheme for Religion}

In this section, I outline my alternate coding scheme for religion. In this alternate scheme, the White Evangelical definition is expanded beyond White Protestants to also include White Catholics and White Latter Day Saint (LDS) members who identify as "born again” or Evangelical Christians. Overall, $0.7 \%$ of the sample identify as White Evangelical Catholic, while $0.2 \%$ identify as White Evangelical LDS members. Expanding the definition to include Evangelical Catholics and LDS members therefore increases the number of respondents who meet the criteria from $N=927(14.50 \%$ of the sample) to $N=991(15.74 \%$ of the sample).

I recode a number of existing religious classifications to avoid problems related to multicollinearity whilst trying to keep my scheme largely congruous with the PRRI classifications used in the main paper. The White Catholic item is recoded to include nonEvangelical Catholics only. In the recoded "other" Christian item, groups now include nonEvangelical LDS members of any race (1.00\%), Orthodox Christians (0.35\%), Black Catholics $(0.45 \%)$, and Protestants and Catholics of any other race (2.25\%). A sample breakdown of my alternate classification scheme is presented in Table A2.1.

Does expanding the definition of White Evangelicals to include Evangelical Catholics and LDS members bias the coefficient relative to the estimates presented in the main paper? The results in Tables A2.2-.6 suggest that, largely, it does not. The tables present the coefficient estimates for the White Evangelical item using the alternative definition in the rerun models that also control for the same set of covariates outlined in the methods section. To aid comparison, the coefficient estimates for the White Evangelical Protestant item are displayed alongside those of the re-estimated models that use the alternative measure. As indicated in these tables, the re-estimated models using the alternate measure do not appear to substantively differ from those presented in the main paper in terms of direction or 
significance. It is only in the case of evaluations of Biden's religiosity that the White Evangelical coefficient becomes insignificant relative to the estimates presented in the main paper. However, the coefficient remains negatively associated with the dependent measure. Given these results, we can express a relative degree of confidence that limiting the definition of Evangelicals to Protestants only is not leading to wildly diverging estimates across model specifications.

Table A2.1: Sample Breakdown by Alternative Religious Classification

\begin{tabular}{lc}
\hline \multicolumn{1}{c}{ Category } & \% of Sample \\
\hline White mainline Protestant & $13.08 \%$ \\
\hline White Evangelical & $15.74 \%$ \\
\hline Black Protestant & $9.35 \%$ \\
\hline Hispanic Protestant & $3.17 \%$ \\
\hline White Catholic & $9.95 \%$ \\
\hline Hispanic Catholic & $6.58 \%$ \\
\hline Other Christian & $4.05 \%$ \\
\hline Non-Christian & $8.80 \%$ \\
\hline Unaffiliated & $29.38 \%$
\end{tabular}

Notes: Weighted estimates.

Table A2.2: Preferences for Elite Religiosity Using Alternative White Evangelical Measure

\begin{tabular}{lcc}
\hline & $\begin{array}{c}\text { Including Evangelical } \\
\text { Catholics + LDS }\end{array}$ & $\begin{array}{c}\text { Evangelical Protestant } \\
\text { Only }\end{array}$ \\
\hline $\boldsymbol{\beta}_{\text {WhiteEvangelical }}$ & $.023^{* * *}$ & $.023^{* * *}$ \\
& $(.003)$ & $(.004)$ \\
\hline Constant & .606 & $.606 * * *$ \\
& $(.002)$ & $(.002)$ \\
\hline $\boldsymbol{R}^{\mathbf{2}}$ & .523 & .523 \\
$\mathrm{~N}$ & 5,981 & 5,981 \\
\hline
\end{tabular}

Notes: Table entries are standardized OLS coefficients. Robust standard errors given in parentheses. Data are weighted. $* p=<.05 * * p=<.01 * * * p=<.001$. 
Table A2.3: Evaluations of Elite Religiosity Using Alternative White Evangelical Measure

\begin{tabular}{lcc}
\hline & Including Evangelical Catholics + & Evangelical Protestant Only \\
\hline Trump & LDS & .033 \\
& .047 & $(.023)$ \\
\hline /cut1 & $.022)$ & $-.184[.021]$ \\
/cut2 & $-.184[.021]$ & $.669[.025]$ \\
/cu3 & $.669[.025]$ & $2.085[.049]$ \\
\hline Pseudo $\boldsymbol{R}^{2}$ & $2.085[.049]$ & .184 \\
$\mathrm{~N}$ & .184 & 5,962 \\
\hline
\end{tabular}

Notes: Table entries are ordered probit coefficients. Robust standard errors given in parentheses. Data are weighted. $* p=<.05 * * p=<.01 * * * p=<.001$.

Table A2.4: Evaluations of Rep/Dem Elite Religiosity Using Alternative White Evangelical Measure

\begin{tabular}{|c|c|c|c|c|c|c|c|c|c|c|}
\hline & \multicolumn{2}{|c|}{ Sanders } & \multicolumn{2}{|c|}{ Warren } & \multicolumn{2}{|c|}{ Biden } & \multicolumn{2}{|c|}{ Buttigieg } & \multicolumn{2}{|c|}{ Pence } \\
\hline & $\begin{array}{c}\text { Including } \\
\text { Evangelical } \\
\text { Catholics + } \\
\text { LDS }\end{array}$ & $\begin{array}{l}\text { Evangelical } \\
\text { Protestant } \\
\text { Only }\end{array}$ & $\begin{array}{c}\text { Including } \\
\text { Evangelical } \\
\text { Catholics + } \\
\text { LDS }\end{array}$ & $\begin{array}{c}\text { Evangelical } \\
\text { Protestant } \\
\text { Only }\end{array}$ & $\begin{array}{c}\text { Including } \\
\text { Evangelical } \\
\text { Catholics + } \\
\text { LDS }\end{array}$ & $\begin{array}{c}\text { Evangelical } \\
\text { Protestant } \\
\text { Only }\end{array}$ & $\begin{array}{c}\text { Including } \\
\text { Evangelical } \\
\text { Catholics + } \\
\text { LDS }\end{array}$ & $\begin{array}{c}\text { Evangelical } \\
\text { Protestant } \\
\text { Only }\end{array}$ & $\begin{array}{c}\text { Including } \\
\text { Evangelical } \\
\text { Catholics + } \\
\text { LDS }\end{array}$ & $\begin{array}{c}\text { Evangelical } \\
\text { Protestant } \\
\text { Only }\end{array}$ \\
\hline $\boldsymbol{\beta}_{\text {WhiteEvangelical }}$ & $\begin{array}{c}-.075 * * \\
(.024)\end{array}$ & $\begin{array}{c}-.101 * * * \\
(.024)\end{array}$ & $\begin{array}{c}-.081 * * * \\
(.024)\end{array}$ & $\begin{array}{c}-.099 * * * \\
(.024)\end{array}$ & $\begin{array}{l}-.040 \\
(.022)\end{array}$ & $\begin{array}{c}-.077 * * \\
(.023)\end{array}$ & $\begin{array}{c}-.076^{* *} \\
(.027)\end{array}$ & $\begin{array}{c}-.085^{* *} \\
(.028)\end{array}$ & $\begin{array}{c}.076 * * * \\
(.024)\end{array}$ & $\begin{array}{c}.072 * * * \\
(.024)\end{array}$ \\
\hline $\begin{array}{l}\text { /cut1 } \\
\text { /cut2 } \\
\text { /cut3 }\end{array}$ & $\begin{array}{c}-.717[.022] \\
.425[.021] \\
1.911[.046]\end{array}$ & $\begin{array}{c}-.716[.022] \\
.428[.021] \\
1.913[.046] \\
\end{array}$ & $\begin{array}{c}-1.059[.027] \\
.205[.021] \\
1.978[.050]\end{array}$ & $\begin{array}{c}-1.059[.027] \\
.206[.021] \\
1.980[.051]\end{array}$ & $\begin{array}{c}-1.430[.032] \\
-.315[.021] \\
1.411[.031]\end{array}$ & $\begin{array}{c}-1.431[.032] \\
-.313[.021] \\
1.416[.031]\end{array}$ & $\begin{array}{c}-1.047[.029] \\
.088[.023] \\
1.658[.040]\end{array}$ & $\begin{array}{c}-1.047[.029] \\
.088[.023] \\
1.658[.040]\end{array}$ & $\begin{array}{c}-1.741[.037] \\
-.964[.025] \\
.006[.020]\end{array}$ & $\begin{array}{c}-1.741[.037] \\
-.964[.025] \\
.006[.020]\end{array}$ \\
\hline $\begin{array}{l}\text { Pseudo } \boldsymbol{R}^{2} \\
\mathrm{~N}\end{array}$ & $\begin{array}{c}.069 \\
5,795 \\
\end{array}$ & $\begin{array}{c}.069 \\
5,795 \\
\end{array}$ & $\begin{array}{c}.082 \\
5,383 \\
\end{array}$ & $\begin{array}{c}.082 \\
5,383 \\
\end{array}$ & $\begin{array}{c}.080 \\
5,807 \\
\end{array}$ & $\begin{array}{c}.081 \\
5,807\end{array}$ & $\begin{array}{c}.059 \\
4,638 \\
\end{array}$ & $\begin{array}{l}.059 \\
4,638 \\
\end{array}$ & $\begin{array}{c}.059 \\
5,681 \\
\end{array}$ & $\begin{array}{c}.059 \\
5,681\end{array}$ \\
\hline
\end{tabular}

Notes: Table entries are ordered probit coefficients. Robust standard errors given in parentheses. Data are weighted. $* p=<.05 * * p=<.01 * * * p=<.001$. 
Table A2.5: Minority Status Perceptions Using Alternative White Evangelical Measure

\begin{tabular}{lcc}
\hline & Including Evangelical & Evangelical Protestant \\
Catholics + LDS & Only \\
\hline $\boldsymbol{\beta}_{\text {WhiteEvangelical }}$ & $.140 * *$ & $.224 * * *$ \\
& $(.027)$ & $(.023)$ \\
\hline Constant & $-.699 * * *$ & $-.714 * * *$ \\
& $(.021)$ & $(.021)$ \\
\hline $\boldsymbol{R}^{\mathbf{2}}$ & .037 & .037 \\
$\mathrm{~N}$ & 5,950 & 5,950 \\
\hline
\end{tabular}

Notes: Table entries are probit coefficients. Robust standard errors given in parentheses. Data are weighted. $* p=<.05 * * p=<.01 * * * p=<.001$.

Table A2.6: Trump's Election as a Divine Outcome Using Alternative White

\section{Evangelical Measure}

\begin{tabular}{|c|c|c|c|c|c|c|}
\hline & \multicolumn{2}{|c|}{$\begin{array}{c}\text { God chose Trump to be } \\
\text { President }\end{array}$} & \multicolumn{2}{|c|}{$\begin{array}{c}\text { God chose Trump to be } \\
\text { President }\end{array}$} & \multicolumn{2}{|c|}{$\begin{array}{l}\text { God does not get involved } \\
\text { in elections }\end{array}$} \\
\hline & $\begin{array}{c}\text { Including } \\
\text { Evangelical } \\
\text { Catholics + } \\
\text { LDS }\end{array}$ & $\begin{array}{c}\text { Evangelical } \\
\text { Protestant } \\
\text { Only }\end{array}$ & $\begin{array}{c}\text { Including } \\
\text { Evangelical } \\
\text { Catholics + } \\
\text { LDS }\end{array}$ & $\begin{array}{c}\text { Evangelical } \\
\text { Protestant } \\
\text { Only }\end{array}$ & $\begin{array}{c}\text { Including } \\
\text { Evangelical } \\
\text { Catholics + } \\
\text { LDS }\end{array}$ & $\begin{array}{c}\text { Evangelical } \\
\text { Protestant } \\
\text { Only }\end{array}$ \\
\hline$\beta_{\text {WhiteEvangelical }}$ & $\begin{array}{l}.413 * \\
(.202)\end{array}$ & $\begin{array}{l}.409 * \\
(.200)\end{array}$ & $\begin{array}{l}.410^{*} \\
(.190)\end{array}$ & $\begin{array}{l}.409 * \\
(.196)\end{array}$ & $\begin{array}{l}.166 \\
(.197)\end{array}$ & $\begin{array}{l}.153 \\
(.194)\end{array}$ \\
\hline
\end{tabular}

Notes: Table entries are multinomial probit coefficients. Robust standard errors given in parentheses. Data are weighted. Reference category for dependent measure is $4=$ "I do not believe in God." The White Evangelical measure remains uninteracted with the minority status perception measure in both models. $* p<.05 * * p<.01$ $* * * p<.001$.

Source: American Trends Panel (Wave 61). 
Table A3: OLS Estimates of Preferences for Elite Religiosity

\begin{tabular}{|c|c|}
\hline & Elite religiosity index \\
\hline White Evangelical Protestant & $\begin{array}{c}.023 * * * \\
(.004)\end{array}$ \\
\hline Black Protestant & $\begin{array}{c}.023^{* * * *} \\
(.005)\end{array}$ \\
\hline Hispanic Protestant & $\begin{array}{l}.013 * * \\
(.003)\end{array}$ \\
\hline White Catholic & $\begin{array}{l}-.002 \\
(.003)\end{array}$ \\
\hline Hispanic Catholic & $\begin{array}{c}.005 \\
(.004) \\
\end{array}$ \\
\hline Other Christian & $\begin{array}{l}.007 * \\
(.003) \\
\end{array}$ \\
\hline Non-Christian & $\begin{array}{l}-.006 \\
(.004)\end{array}$ \\
\hline Unaffiliated & $\begin{array}{c}-.016 * * \\
(.006)\end{array}$ \\
\hline Importance of religion & $\begin{array}{c}.105 * * * \\
(.008)\end{array}$ \\
\hline Religious service attendance & $\begin{array}{l}.014 * * \\
(.005)\end{array}$ \\
\hline Frequency of prayer & $\begin{array}{c}.023 * * * \\
(.006)\end{array}$ \\
\hline Republican & $\begin{array}{c}.026 * * * \\
(.004)\end{array}$ \\
\hline Ideology (conservative) & $\begin{array}{c}.033 * * * \\
(.005)\end{array}$ \\
\hline Age & $\begin{array}{c}.026 * * * \\
(.003)\end{array}$ \\
\hline Male & $\begin{array}{c}-.010 * * \\
(.003)\end{array}$ \\
\hline Education & $\begin{array}{c}-.032 * * \\
(.003)\end{array}$ \\
\hline South & $\begin{array}{c}.006 \\
(.0030 \\
\end{array}$ \\
\hline Constant & $\begin{array}{c}.519 * * * \\
(.003)\end{array}$ \\
\hline $\begin{array}{l}\boldsymbol{R}^{\mathbf{2}} \\
N\end{array}$ & $\begin{array}{c}.523 \\
5,981 \\
\end{array}$ \\
\hline
\end{tabular}

Notes: Table entries are standardized OLS coefficients. Robust standard errors given in parentheses. Data are weighted. $* p<.05 * * p<.01 * * * p<.001$.

Source: American Trends Panel (Wave 61). 
Table A4: Ordered Probit Estimates of Preferences for Elite Religiosity

\begin{tabular}{|c|c|c|c|}
\hline & $\begin{array}{c}\text { Shares my religious } \\
\text { beliefs }\end{array}$ & $\begin{array}{c}\text { Has strong religious } \\
\text { beliefs }\end{array}$ & $\begin{array}{l}\text { Stands up for } \\
\text { people with my } \\
\text { religious beliefs }\end{array}$ \\
\hline White Evangelical Protestant & $\begin{array}{c}.157 * * * \\
(.021)\end{array}$ & $\begin{array}{l}-.027 \\
(.023)\end{array}$ & $\begin{array}{c}.153 * * * \\
(.023)\end{array}$ \\
\hline Black Protestant & $\begin{array}{c}.139 * * * \\
(.026)\end{array}$ & $\begin{array}{c}.050 \\
(.029)\end{array}$ & $\begin{array}{l}.085 * * \\
(.025)\end{array}$ \\
\hline Hispanic Protestant & $\begin{array}{l}.072 * * \\
(.026)\end{array}$ & $\begin{array}{c}.011 \\
(.022)\end{array}$ & $\begin{array}{c}.081 * * * \\
(.022)\end{array}$ \\
\hline White Catholic & $\begin{array}{l}-.022 \\
(.018)\end{array}$ & $\begin{array}{l}-.016 \\
(.020)\end{array}$ & $\begin{array}{l}.014 \\
(.019)\end{array}$ \\
\hline Hispanic Catholic & $\begin{array}{l}.071 * * \\
(.025)\end{array}$ & $\begin{array}{c}.013 \\
(.023)\end{array}$ & $\begin{array}{l}-.010 \\
(.023)\end{array}$ \\
\hline Other Christian & $\begin{array}{l}.024 \\
(.019)\end{array}$ & $\begin{array}{l}.007 \\
(.019)\end{array}$ & $\begin{array}{l}.053 * * \\
(.019)\end{array}$ \\
\hline Non-Christian & $\begin{array}{l}-.050 \\
(.027)\end{array}$ & $\begin{array}{l}-.047 \\
(.025)\end{array}$ & $\begin{array}{l}.042 \\
(.024)\end{array}$ \\
\hline Unaffiliated & $\begin{array}{l}-.011 \\
(.030)\end{array}$ & $\begin{array}{c}-.150 * * * \\
(.030)\end{array}$ & $\begin{array}{l}-.013 \\
(.029)\end{array}$ \\
\hline Importance of religion & $\begin{array}{c}.423 * * * \\
(.042)\end{array}$ & $\begin{array}{c}.492 * * * \\
(.039)\end{array}$ & $\begin{array}{c}.346 * * * \\
(.039)\end{array}$ \\
\hline Religious service attendance & $\begin{array}{l}.087 * * \\
(.027)\end{array}$ & $\begin{array}{c}.016 \\
(.029)\end{array}$ & $\begin{array}{l}.084 * * \\
(.027)\end{array}$ \\
\hline Frequency of prayer & $\begin{array}{c}.108 * * * \\
(.034)\end{array}$ & $\begin{array}{c}.131 * * * \\
(.032)\end{array}$ & $\begin{array}{c}.050 \\
(.030)\end{array}$ \\
\hline Republican & $\begin{array}{c}.149 * * * \\
(.025)\end{array}$ & $\begin{array}{l}.073 * * \\
(.025)\end{array}$ & $\begin{array}{c}.101 * * * \\
(.024)\end{array}$ \\
\hline Ideology (conservative) & $\begin{array}{c}.169 * * * \\
(.060)\end{array}$ & $\begin{array}{c}.176^{* * * *} \\
(.028)\end{array}$ & $\begin{array}{c}.103 * * * \\
(.028)\end{array}$ \\
\hline Age & $\begin{array}{l}.040 * \\
(.020)\end{array}$ & $\begin{array}{c}.186^{* * * *} \\
(.019)\end{array}$ & $\begin{array}{c}.098 * * * \\
(.019)\end{array}$ \\
\hline Male & $\begin{array}{l}-.032 \\
(.020)\end{array}$ & $\begin{array}{c}-.064 * * \\
(.019)\end{array}$ & $\begin{array}{l}-.039 * \\
(.019)\end{array}$ \\
\hline Education & $\begin{array}{c}-.184 * * * \\
(.020)\end{array}$ & $\begin{array}{c}-.209 * * * \\
(.019)\end{array}$ & $\begin{array}{l}-.015 \\
(.019)\end{array}$ \\
\hline South & $\begin{array}{l}.061 * * \\
(.019)\end{array}$ & $\begin{array}{l}.035 \\
(.019)\end{array}$ & $\begin{array}{l}-.008 \\
(.019)\end{array}$ \\
\hline $\begin{array}{l}\text { /cut1 } \\
\text { /cut2 } \\
\text { /cut3 }\end{array}$ & $\begin{array}{l}-.679[.025] \\
.437[.023] \\
1.521[.024]\end{array}$ & $\begin{array}{l}-1.068[.029] \\
-.034[.022] \\
1.204[.028]\end{array}$ & $\begin{array}{c}-1.447[.028] \\
-.644[.022] \\
.344[.021]\end{array}$ \\
\hline $\begin{array}{l}\text { Pseudo } \boldsymbol{R}^{\mathbf{2}} \\
N\end{array}$ & $\begin{array}{c}.197 \\
6,024\end{array}$ & $\begin{array}{c}.211 \\
6,007\end{array}$ & $\begin{array}{c}.128 \\
6,015\end{array}$ \\
\hline
\end{tabular}

Notes: Table entries are ordered probit coefficients. Robust standard errors given in parentheses. Data are weighted. $* p<.05 * * p<.01 * * * p<.001$.

Source: American Trends Panel (Wave 61). 
Table A5: Ordered Probit Estimates for Evaluations of Trump's Religiosity

\begin{tabular}{|c|c|}
\hline & How religious is Trump? \\
\hline White Evangelical Protestant & $\begin{array}{c}.033 \\
(.023) \\
\end{array}$ \\
\hline Black Protestant & $\begin{array}{c}-.157 * * * \\
(.030)\end{array}$ \\
\hline Hispanic Protestant & $\begin{array}{l}-.006 \\
(.024)\end{array}$ \\
\hline White Catholic & $\begin{array}{l}-.015 \\
(.020)\end{array}$ \\
\hline Hispanic Catholic & $\begin{array}{l}-.014 \\
(.027)\end{array}$ \\
\hline Other Christian & $\begin{array}{l}-.043^{*} \\
(.020)\end{array}$ \\
\hline Non-Christian & $\begin{array}{l}-.023 \\
(.025)\end{array}$ \\
\hline Unaffiliated & $\begin{array}{l}-.024 \\
(.032)\end{array}$ \\
\hline Importance of religion & $\begin{array}{l}.081 * \\
(.039)\end{array}$ \\
\hline Religious service attendance & $\begin{array}{l}-.005 \\
(.030)\end{array}$ \\
\hline Frequency of prayer & $\begin{array}{l}-.030 \\
(.033) \\
\end{array}$ \\
\hline Republican & $\begin{array}{c}.576 * * * \\
(.027) \\
\end{array}$ \\
\hline Ideology (conservative) & $\begin{array}{c}.243 * * * \\
(.020)\end{array}$ \\
\hline Age & $\begin{array}{l}-.023 \\
(.020)\end{array}$ \\
\hline Male & $\begin{array}{l}-.038 \\
(.021)\end{array}$ \\
\hline Education & $\begin{array}{c}-.155 * * * \\
(.020)\end{array}$ \\
\hline South & $\begin{array}{c}.008 \\
(.021) \\
\end{array}$ \\
\hline $\begin{array}{l}\text { /cut1 } \\
\text { /cut2 } \\
\text { /cut3 }\end{array}$ & $\begin{array}{c}-.184[.021] \\
.669[.025] \\
2.085[.049]\end{array}$ \\
\hline $\begin{array}{l}\text { Pseudo } \boldsymbol{R}^{\mathbf{2}} \\
N\end{array}$ & $\begin{array}{c}.184 \\
5,962 \\
\end{array}$ \\
\hline
\end{tabular}

Notes: Table entries are ordered probit. Robust standard errors given in parentheses. Data are weighted. $* p<.05 * * p<.01 * * * p<.001$.

Source: American Trends Panel (Wave 61). 
Table A6: Ordered Probit Estimates for Evaluations of Rep/Dem Elite Religiosity

\begin{tabular}{|c|c|c|c|c|c|}
\hline & Sanders & Warren & Biden & Buttigieg & Pence \\
\hline $\begin{array}{l}\text { White Evangelical } \\
\text { Protestant }\end{array}$ & $\begin{array}{c}-.101 * * * \\
(.024)\end{array}$ & $\begin{array}{c}-.099 * * * \\
(.024)\end{array}$ & $\begin{array}{c}-.077 * * \\
(.023)\end{array}$ & $\begin{array}{l}-.085 * * \\
(.028)\end{array}$ & $\begin{array}{c}.072 * * * \\
(.024)\end{array}$ \\
\hline Black Protestant & $\begin{array}{c}.103 * * * \\
(.025)\end{array}$ & $\begin{array}{l}.064 * \\
(.027)\end{array}$ & $\begin{array}{l}.032 \\
(.025)\end{array}$ & $\begin{array}{l}-.007 \\
(.028)\end{array}$ & $\begin{array}{c}-.174 * * * \\
(.025)\end{array}$ \\
\hline Hispanic Protestant & $\begin{array}{l}.007 \\
(.027)\end{array}$ & $\begin{array}{l}.015 \\
(.024)\end{array}$ & $\begin{array}{l}-.032 \\
(.028)\end{array}$ & $\begin{array}{l}-.012 \\
(.029)\end{array}$ & $\begin{array}{l}-.024 \\
(.021)\end{array}$ \\
\hline White Catholic & $\begin{array}{l}-.008 \\
(.021)\end{array}$ & $\begin{array}{l}-.011 \\
(.022)\end{array}$ & $\begin{array}{l}.043 * \\
(.021)\end{array}$ & $\begin{array}{l}.012 \\
(.022)\end{array}$ & $\begin{array}{l}.018 \\
(.021)\end{array}$ \\
\hline Hispanic Catholic & $\begin{array}{l}.011 \\
(.024)\end{array}$ & $\begin{array}{l}.036 \\
(.029)\end{array}$ & $\begin{array}{l}.018 \\
(.024)\end{array}$ & $\begin{array}{l}.004 \\
(.032)\end{array}$ & $\begin{array}{l}-.054^{*} \\
(.024)\end{array}$ \\
\hline Other Christian & $\begin{array}{l}-.024 \\
(.020)\end{array}$ & $\begin{array}{l}.002 \\
(.021)\end{array}$ & $\begin{array}{l}-.024 \\
(.019)\end{array}$ & $\begin{array}{l}-.038 \\
(.024)\end{array}$ & $\begin{array}{l}-.019 \\
(.019)\end{array}$ \\
\hline Non-Christian & $\begin{array}{l}-.066 \\
(.026)\end{array}$ & $\begin{array}{l}-.041 \\
(.027)\end{array}$ & $\begin{array}{c}-.081 * * \\
(.024)\end{array}$ & $\begin{array}{l}.002 \\
(.027)\end{array}$ & $\begin{array}{l}-.010 \\
(.028)\end{array}$ \\
\hline Unaffiliated & $\begin{array}{l}-.051 \\
(.032)\end{array}$ & $\begin{array}{l}-.037 \\
(.034)\end{array}$ & $\begin{array}{l}-.029 \\
(.031)\end{array}$ & $\begin{array}{l}.051 \\
(.035)\end{array}$ & $\begin{array}{l}.002 \\
(.032)\end{array}$ \\
\hline $\begin{array}{l}\text { Importance of } \\
\text { religion }\end{array}$ & $\begin{array}{l}.039 \\
(.040)\end{array}$ & $\begin{array}{l}.074 \\
(.040)\end{array}$ & $\begin{array}{l}.051 \\
(.035)\end{array}$ & $\begin{array}{l}.036 \\
(.042)\end{array}$ & $\begin{array}{l}-.085^{*} \\
(.037)\end{array}$ \\
\hline $\begin{array}{l}\text { Religious service } \\
\text { attendance }\end{array}$ & $\begin{array}{l}-.075 \\
(.030)\end{array}$ & $\begin{array}{l}.006 \\
(.033)\end{array}$ & $\begin{array}{l}-.006 \\
(.028)\end{array}$ & $\begin{array}{l}-.024 \\
(.034)\end{array}$ & $\begin{array}{l}.067^{*} \\
(.029)\end{array}$ \\
\hline Frequency of prayer & $\begin{array}{c}.014 \\
(.032)\end{array}$ & $\begin{array}{l}-.093 * * \\
(.034)\end{array}$ & $\begin{array}{l}-.055 \\
(.030)\end{array}$ & $\begin{array}{l}-.068 \\
(.032)\end{array}$ & $\begin{array}{c}-.133 * * * \\
(.031)\end{array}$ \\
\hline Republican & $\begin{array}{c}-.291 * * * \\
(.026)\end{array}$ & $\begin{array}{c}-.304 * * * \\
(.029)\end{array}$ & $\begin{array}{c}-.378 * * * \\
(.026)\end{array}$ & $\begin{array}{c}-.237 * * * \\
(.030)\end{array}$ & $\begin{array}{l}.074 * * \\
(.024)\end{array}$ \\
\hline $\begin{array}{l}\text { Ideology } \\
\text { (conservative) }\end{array}$ & $\begin{array}{c}-.081 * * \\
(.028)\end{array}$ & $\begin{array}{c}-.194 * * * \\
(.028)\end{array}$ & $\begin{array}{c}-.129 * * * \\
(.028)\end{array}$ & $\begin{array}{c}-.186 * * * \\
(.033)\end{array}$ & $\begin{array}{l}.015 \\
(.026) \\
\end{array}$ \\
\hline Age & $\begin{array}{l}-.022 \\
(.020)\end{array}$ & $\begin{array}{c}.099 * * * \\
(.021)\end{array}$ & $\begin{array}{c}.105^{* * * *} \\
(.019)\end{array}$ & $\begin{array}{l}.074 * * \\
(.022)\end{array}$ & $\begin{array}{c}.122 * * * \\
(.020)\end{array}$ \\
\hline Male & $\begin{array}{c}-.110 * * * \\
(.019)\end{array}$ & $\begin{array}{c}-.056^{* *} \\
(.020)\end{array}$ & $\begin{array}{l}-.026 \\
(.019)\end{array}$ & $\begin{array}{l}-.014 \\
(.021)\end{array}$ & $\begin{array}{c}.112 * * * \\
(.020)\end{array}$ \\
\hline Education & $\begin{array}{c}-.161 * * * \\
(.019)\end{array}$ & $\begin{array}{c}-.152 * * * \\
(.021)\end{array}$ & $\begin{array}{l}.041 * \\
(.019)\end{array}$ & $\begin{array}{c}.004 \\
(.022)\end{array}$ & $\begin{array}{c}.235^{* * * *} \\
(.021) \\
\end{array}$ \\
\hline South & $\begin{array}{c}.016 \\
(.020)\end{array}$ & $\begin{array}{c}.018 \\
(.021)\end{array}$ & $\begin{array}{l}-.015 \\
(.019)\end{array}$ & $\begin{array}{l}-.023 \\
(.022)\end{array}$ & $\begin{array}{l}-.014 \\
(.020)\end{array}$ \\
\hline $\begin{array}{l}\text { /cut1 } \\
\text { /cut2 } \\
\text { /cut3 }\end{array}$ & $\begin{array}{c}-.716[.022] \\
.428[.021] \\
1.913[.046]\end{array}$ & $\begin{array}{c}-1.059[.027] \\
.206[.021] \\
1.980[.051]\end{array}$ & $\begin{array}{c}-1.431[.032] \\
-.313[.021] \\
1.416[.031]\end{array}$ & $\begin{array}{c}-1.047[.029] \\
.088[.023] \\
1.658[.040]\end{array}$ & $\begin{array}{c}-1.741[.037] \\
-.964[.025] \\
.006[.020]\end{array}$ \\
\hline $\begin{array}{l}\text { Pseudo } \boldsymbol{R}^{\mathbf{2}} \\
N\end{array}$ & $\begin{array}{c}.069 \\
5,795\end{array}$ & $\begin{array}{c}.082 \\
5,383 \\
\end{array}$ & $\begin{array}{c}.081 \\
5,807 \\
\end{array}$ & $\begin{array}{c}.059 \\
4,638\end{array}$ & $\begin{array}{c}.059 \\
5,681 \\
\end{array}$ \\
\hline
\end{tabular}

Notes: Table entries are standardized OLS coefficients. Robust standard errors given in parentheses. Data are weighted. $* p<.05 * * p<.01 * * * p<.001$.

Source: American Trends Panel (Wave 61). 


\section{Table A7: Probit Estimates for Minority Status Perceptions}

\begin{tabular}{|c|c|}
\hline & $\begin{array}{l}\text { Does R consider self minority because of } \\
\text { religious beliefs? }\end{array}$ \\
\hline White Evangelical Protestant & $\begin{array}{c}.224 * * * \\
(.023)\end{array}$ \\
\hline Black Protestant & $\begin{array}{l}.143 * * * \\
(.034)\end{array}$ \\
\hline Hispanic Protestant & $\begin{array}{l}.091 * * * \\
(.028)\end{array}$ \\
\hline White Catholic & $\begin{array}{l}.017 \\
(.033)\end{array}$ \\
\hline Hispanic Catholic & $\begin{array}{l}.057 \\
(.034)\end{array}$ \\
\hline Other Christian & $\begin{array}{l}.139 * * * \\
(.024)\end{array}$ \\
\hline Non-Christian & $\begin{array}{l}.400 * * * \\
(.031)\end{array}$ \\
\hline Unaffiliated & $\begin{array}{l}.315 * * * \\
(.044)\end{array}$ \\
\hline Importance of religion & $\begin{array}{l}.055 \\
(.049)\end{array}$ \\
\hline Religious service attendance & $\begin{array}{c}.181 * * * \\
(.037)\end{array}$ \\
\hline Frequency of prayer & $\begin{array}{c}.021 \\
(.042)\end{array}$ \\
\hline Republican & $\begin{array}{l}.031 \\
(.032)\end{array}$ \\
\hline Ideology (conservative) & $\begin{array}{l}-.027 \\
(.033)\end{array}$ \\
\hline Age & $\begin{array}{l}-.025 \\
(.024)\end{array}$ \\
\hline Male & $\begin{array}{l}.054 * \\
(.024)\end{array}$ \\
\hline Education & $\begin{array}{l}.072 * * \\
(.024)\end{array}$ \\
\hline South & $\begin{array}{l}-.009 \\
(.024)\end{array}$ \\
\hline Constant & $\begin{array}{c}-.714 * * * \\
(.021)\end{array}$ \\
\hline $\begin{array}{l}\text { Pseudo } \boldsymbol{R}^{2} \\
N\end{array}$ & $\begin{array}{c}.037 \\
5,950\end{array}$ \\
\hline
\end{tabular}

Notes: Table entries are probit coefficients. Robust standard errors given in parentheses. Data are weighted. $* p<.05 * * p<.01 * * * p<.001$.

Source: American Trends Panel (Wave 61). 
Table A8: Ordered Probit Estimates for Marginalized Group Perceptions

\begin{tabular}{|c|c|}
\hline & $\begin{array}{l}\text { Beliefs in conflict with mainstream US } \\
\text { culture }\end{array}$ \\
\hline White Evangelical Protestant & $\begin{array}{c}.196 * * * \\
(.022)\end{array}$ \\
\hline Black Protestant & $\begin{array}{l}-.041 \\
(.024) \\
\end{array}$ \\
\hline Hispanic Protestant & $\begin{array}{l}-.021 \\
(.023)\end{array}$ \\
\hline White Catholic & $\begin{array}{l}.010 \\
(.018)\end{array}$ \\
\hline Hispanic Catholic & $\begin{array}{c}-.062 * * \\
(.022)\end{array}$ \\
\hline Other Christian & $\begin{array}{l}.035 \\
(.019)\end{array}$ \\
\hline Non-Christian & $\begin{array}{c}.109 * * * \\
(.024)\end{array}$ \\
\hline Unaffiliated & $\begin{array}{c}.036 \\
(.029)\end{array}$ \\
\hline Importance of religion & $\begin{array}{l}.005 \\
(.037)\end{array}$ \\
\hline Religious service attendance & $\begin{array}{l}.201 * * * \\
(.027)\end{array}$ \\
\hline Frequency of prayer & $\begin{array}{l}.086 * * \\
(.031)\end{array}$ \\
\hline Republican & $\begin{array}{l}.065 * * \\
(.024) \\
\end{array}$ \\
\hline Ideology (conservative) & $\begin{array}{l}-.023 \\
(.025)\end{array}$ \\
\hline Age & $\begin{array}{c}-.083 * * * \\
(.019)\end{array}$ \\
\hline Male & $\begin{array}{l}.060 * * \\
(.019)\end{array}$ \\
\hline Education & $\begin{array}{c}.102 * * * \\
(.019)\end{array}$ \\
\hline South & $\begin{array}{l}-.001 \\
(.019)\end{array}$ \\
\hline $\begin{array}{l}\text { /cut1 } \\
\text { /cut2 } \\
\text { /cut3 }\end{array}$ & $\begin{array}{c}-.761[.022] \\
.152[.019] \\
1.188[.026]\end{array}$ \\
\hline $\begin{array}{l}\text { Pseudo } \boldsymbol{R}^{2} \\
N\end{array}$ & $\begin{array}{c}.048 \\
5,962\end{array}$ \\
\hline
\end{tabular}

Source: American Trends Panel (Wave 61). 
A9: Full Model Estimations for Trump's Election as a Divine Outcome

Table A9: Multinomial Probit Estimates for Trump's Election as a Divine

\section{Outcome}

\begin{tabular}{|c|c|c|c|}
\hline & $\begin{array}{l}\text { God chose Trump to } \\
\text { be President }\end{array}$ & $\begin{array}{l}\text { Trump's election } \\
\text { part of God's plan }\end{array}$ & $\begin{array}{l}\text { God does not get } \\
\text { involved in excitons }\end{array}$ \\
\hline White Evangelical Protestant & $\begin{array}{l}.107 \\
(.178)\end{array}$ & $\begin{array}{l}.123 \\
(.173)\end{array}$ & $\begin{array}{l}-.118 \\
(.172)\end{array}$ \\
\hline Minority because of religious beliefs & $\begin{array}{l}-.161 \\
(.097)\end{array}$ & $\begin{array}{c}-.334 * * * \\
(.079)\end{array}$ & $\begin{array}{c}-.446 * * * \\
(.070)\end{array}$ \\
\hline $\begin{array}{l}\text { White Evangelical Protestant } \mathrm{x} \\
\text { minority because of religious beliefs }\end{array}$ & $\begin{array}{l}-.327 * \\
(.121)\end{array}$ & $\begin{array}{l}-.269 * \\
(.128)\end{array}$ & $\begin{array}{l}-.320^{*} \\
(.128)\end{array}$ \\
\hline Black Protestant & $\begin{array}{c}-.580 * * * \\
(.159)\end{array}$ & $\begin{array}{c}-.537 * * * \\
(.143)\end{array}$ & $\begin{array}{c}-.713 * * * \\
(.140)\end{array}$ \\
\hline Hispanic Protestant & $\begin{array}{l}.178 \\
(.175)\end{array}$ & $\begin{array}{c}-.317 * * \\
(.099)\end{array}$ & $\begin{array}{l}.149 \\
(.168)\end{array}$ \\
\hline White Catholic & $\begin{array}{l}-.143 \\
(.124)\end{array}$ & $\begin{array}{l}-.215^{*} \\
(.110)\end{array}$ & $\begin{array}{l}-.077 \\
(.106)\end{array}$ \\
\hline Hispanic Catholic & $\begin{array}{c}-.312 * * \\
(.118)\end{array}$ & $\begin{array}{c}-.317 * * \\
(.099)\end{array}$ & $\begin{aligned}-.244 * \\
(.095)\end{aligned}$ \\
\hline Other Christian & $\begin{array}{l}.085 \\
(.137)\end{array}$ & $\begin{array}{l}.102 \\
(.128)\end{array}$ & $\begin{array}{l}.099 \\
(.125)\end{array}$ \\
\hline Non-Christian & $\begin{array}{c}-.524 * * * \\
(.121)\end{array}$ & $\begin{array}{c}-.485 * * * \\
(.088)\end{array}$ & $\begin{array}{c}-.410 * * * \\
(.075)\end{array}$ \\
\hline Unaffiliated & $\begin{array}{c}-.581 * * * \\
(.131)\end{array}$ & $\begin{array}{c}-.743 * * * \\
(.111)\end{array}$ & $\begin{array}{c}-.663 * * * \\
(.101)\end{array}$ \\
\hline Importance of religion & $\begin{array}{l}.965 * * * \\
(.158)\end{array}$ & $\begin{array}{l}1.219 * * * \\
(.116)\end{array}$ & $\begin{array}{l}.839 * * * \\
(.101)\end{array}$ \\
\hline Religious service attendance & $\begin{array}{l}.137 \\
(.167)\end{array}$ & $\begin{array}{l}.103 \\
(.158)\end{array}$ & $\begin{array}{l}-.048 \\
(.152)\end{array}$ \\
\hline Frequency of prayer & $\begin{array}{l}1.285 * * * \\
(.157)\end{array}$ & $\begin{array}{l}1.380 * * * \\
(.129)\end{array}$ & $\begin{array}{c}1.081 * * * \\
(.120)\end{array}$ \\
\hline Republican & $\begin{array}{l}.420 * * * \\
(.110)\end{array}$ & $\begin{array}{l}.179 * \\
(.082)\end{array}$ & $\begin{array}{l}.037 \\
(.071)\end{array}$ \\
\hline Ideology (conservative) & $\begin{array}{c}.552 * * * \\
(.136)\end{array}$ & $\begin{array}{c}.386 * * * \\
(.093)\end{array}$ & $\begin{array}{l}.242 * * \\
(.042)\end{array}$ \\
\hline Age & $\begin{array}{l}.004 \\
(.079)\end{array}$ & $\begin{array}{l}-.019 \\
(.064)\end{array}$ & $\begin{array}{l}.213 * * * \\
(.052)\end{array}$ \\
\hline Male & $\begin{array}{l}-.117 \\
(.078)\end{array}$ & $\begin{array}{l}-.147 * \\
(.062)\end{array}$ & $\begin{array}{l}-.086 \\
(.052)\end{array}$ \\
\hline Education & $\begin{array}{c}-.323 * * * \\
(.082)\end{array}$ & $\begin{array}{l}.001 \\
(.063)\end{array}$ & $\begin{array}{l}.057 \\
(.054)\end{array}$ \\
\hline South & $\begin{array}{l}.071 \\
(.081)\end{array}$ & $\begin{array}{l}.024 \\
(.066)\end{array}$ & $\begin{array}{l}-.003 \\
(.058)\end{array}$ \\
\hline Constant & $\begin{array}{c}.752 * * * \\
(.200)\end{array}$ & $\begin{array}{c}2.119 * * * \\
(.186)\end{array}$ & $\begin{array}{c}2.942 * * * \\
(.188)\end{array}$ \\
\hline $\begin{array}{l}\text { Log pseudolikelihood } \\
\mathrm{N}\end{array}$ & $\begin{array}{c}-4473.3437 \\
5,891\end{array}$ & & \\
\hline
\end{tabular}

Notes: Table entries are multinomial probit coefficients. Robust standard errors given in parentheses. Data are weighted. Reference category for dependent measure is $4=$ "I do not believe in God." * $p<.05 * * p<.01 * * * p$ $<.001$.

Source: American Trends Panel (Wave 61). 